\title{
Citizenship, Standing, and Immigration Law
}

\author{
Adam B. Cox $\dagger$
}

TABle of Contents

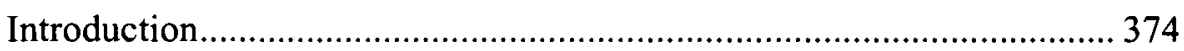

I. The Plenary Power as Standing Doctrine ..........................................377

A. The Scope of Plenary Power Doctrine ....................................... 378

B. Justifications for Plenary Power Doctrine ................................. 381

1. Judicial Deference ............................................................. 382

2. Unlimited Congressional Power.......................................... 384

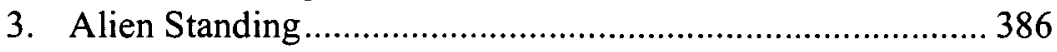

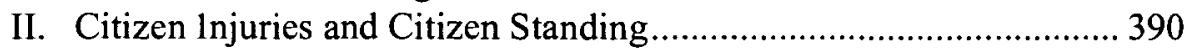

A. Associational lnjuries ............................................................ 391

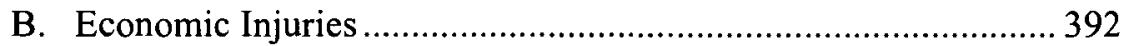

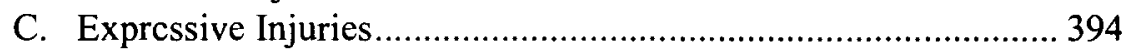

1. Expressive Harms and Standing.........................................394

2. Immigration Law and National Political Identity................. 396

3. Potential Objections .......................................................... 402

a. Political Community Regulation ................................... 402

b. The Limited Role of the Judiciary .................................408

II1. The Implications of Citizen Standing ............................................... 412

A. Constitutional Challenges to Immigration Policy ....................... 412

B. Undermining the Plenary Power ............................................. 417

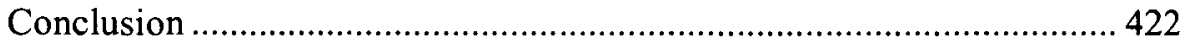

Copyright $\odot 2004$ California Law Review, Inc. California Law Review, Inc. (CLR) is a Califomia nonprofit corporation. CLR and the authors are solely responsible for the content of their publications.

$+\quad$ Bigelow Fellow and Lecturer in Law, University of Chicago Law School. J.D., University of Michigan Law School, 1999; B.S.E., Princeton University, 1996. I would like to thank Ahilan Arulanantham, Rick Bierschbach, Evan Caminker, Mary Anne Case, Adam Feibelman, Elizabeth Garrett, Philip Hamburger, Ryan Goodman, Jenia Iontcheva, Michelle Kim, Elizabeth Milnikel, Chris Newman, Eric Posner, David Strauss, and Cass Sunstein for their generous advice and comments on previous drafts. All errors are my own. 


\title{
Citizenship, Standing, and Immigration Law
}

\author{
Adam B. Cox
}

Courts and commentators typically evaluate constitutional immigration law from the perspective of aliens. But that approach pays insufficient attention to the ways immigration law affects the interests and rights of citizens. In particular, an alien-centered approach fails to consider the central role immigration law plays in national self-definition and, consequently, ignores the possibility that immigration law may injure citizens by defining the national political community in constitutionally impermissible ways. Considering federal immigration law from the perspective of citizens, this Article demonstrates that immigration policy, which contemporary constitutional doctrine largely insulates from attack, should not be immune to challenges by citizens. And contrary to the thrust of contemporary doctrine, courts should scrutinize immigration policy for compliance with conventional constitutional norms when citizens' rights are at stake.

\section{INTRODUCTION}

Courts focus almost exclusively on the rights and interests of aliens when considering challenges to immigration laws. Courts typically treat citizens, who already enjoy the entitlement of residence and the benefits of citizenship, as legally unaffected by immigration laws. Indeed, citizens have been at most an afterthought in the constitutional analysis of immigration policy. The constitutional core of immigration law - the doctrine of Congress's plenary power over immigration - embodies this focus. Plenary power doctrine largely insulates federal immigration law from constitutional attack. ${ }^{1}$ Pursuant to the doctrine, courts approach constitutional challenges to immigration law principally from the perspective of aliens' rights. ${ }^{2}$ Because of this doctrinal focus on aliens, the broad array of scholarship criticizing the plenary power also reflects an alien-centered perspective. $^{3}$

1. See infra text accompanying notes $13,16-31$.

2. See infra Part 11 .

3. See, e.g., Gerald E. Neuman, Strangers to the Constitution: Immigrants, Borders, and Fundamental Law (1996); Gabriel J. Chin, Segregation's Last Stronghold: Race Discrimination and the Constitutional Law of Immigration, 46 UCLA L. Rev. 1 (1998); Stephen H. Legomsky, Immigration Law and the Principle of Plenary Congressional Power, 1984 SUP. CT. REv. 255; Hiroshi 
This Article reorients immigration law discourse by evaluating the plenary power doctrine from the perspective of citizens. The alien-centered approach, 1 will argue, is inadequate and misleading. Citizens do have legally cognizable interests in the substance of immigration law. Moreover, considering plenary power doctrine from the perspective of citizens yields important insights: first, that citizens should be able to challenge the constitutionality of immigration policy much more regularly than is currently thought, and second, that courts should evaluate immigration policy for compliance with conventional constitutional norms when citizens bring suit.

To evaluate the significance of citizens' interests in the immigration context, this Article first unpacks the conceptual structure of Congress's "plenary power" over immigration. The plenary power doctrine is typically interpreted by immigration scholars to reflect judicial deference to, or a lack of constitutional limitations on, Congress's exercise of its immigration power. But as Part I explains, this understanding of plenary power doctrine is incomplete. Often unrecognized is the fact that plenary power doctrine is in large part a doctrine of standing: courts reject constitutional challenges to immigration policy principally on the ground that aliens lack the right to seek judicial review of the constitutionality of immigration policy. These courts conclude that aliens are in some sense "strangers to the Constitution." As such, courts reason, any injuries immigration law inflicts upon aliens are not legally cognizable. And because aliens lack a legally cognizable injury, they cannot contest the constitutionality of immigration policy in court.

Unlike aliens, citizens are full members of the constitutional community. Nonetheless, it is typically thought that citizens cannot be injured by immigration law: after all, citizens already enjoy the entitlement of residence and the benefits of citizenship. As Part II shows, however, citizens can be injured by immigration law in legally cognizable ways. Accordingly, citizens regularly should have standing to challenge immigration laws. Courts sporadically acknowledge that immigration law can

Motomura, Immigration Law After a Century of Plenary Power: Phantom Constitutional Norms and Statutory Interpretation, 100 YALE L.J. 545, 580-93 (1990) [hereinafter Motomura, Phantom Constitutional Norms]. A few immigration law scholars have more recently suggested that the nearexclusive focus on the relationship between aliens and the Constitution may be obscuring some of the complexities of immigration law and policy. See Hiroshi Motomura, Whose Immigration Law?: Citizens, Aliens, and the Constitution, 97 Colum. L. Rev. 1567, 1572 (1997) (reviewing NEUMAN, supra) (arguing that "[u]npacking the complexities of immigration law and policy requires that we consider both aliens' rights and citizens' rights") [hereinafter Motomura, Whose Immigration Law]; Frank H. Wu, The Limits of Borders: A Moderate Proposal for Immigration Reform, 7 STAN. L. \& POL'Y REv. 35 (1996) (arguing that immigration policies impinge on the status of citizens, particularly racial and ethnic minorities that might be perceived as "foreign"). As yet, however, no one has systematically explored the question of how citizens' interests or rights could alter the operation of constitutional immigration law.

4. Neuman, supra note 3. 
cognizably injure citizens-though they typically do so without appreciating the implications of citizen standing. ${ }^{5}$ For example, courts have found in some circumstances that immigration law can interfere with the associational and economic interests of citizens in legally cognizable ways. ${ }^{6}$

While courts have accorded citizens standing to challenge immigration regulation in limited circumstances, Part II argues that citizen standing should sweep much more broadly. Courts should more regularly recognize the economic and associational interests of citizens that immigration law implicates. Moreover, courts should consider the possibility that immigration law can inflict legally cognizable expressive injuries on citizens. Immigration law plays a central role in national self-definition by regulating entrance into the national political community. Citizens, as members of that community, have a substantial interest in how the existing community is constituted. And immigration law can injure citizens by expressing constitutionally impermissible conceptions of national political identity. While this injury may seem at first too abstract or ephemeral for constitutional law to recognize, it is not. In fact, in another area of constitutional law concerning the regulation of political boundaries-electoral redistricting - the Supreme Court has recognized that just such an expressive injury is judicially cognizable. ${ }^{7}$

Part III describes the implications of combining Part II's insight regarding citizen standing with Part I's reconceptualization of the plenary power as a standing doctrine. First, it becomes clear that citizens should be able to challenge the constitutionality of immigration policy more frequently than is currently thought. Moreover, the right of citizens to assert such constitutional challenges should not be merely a formal, empty right. Instead, constitutional challenges to immigration laws by citizens should result in greater judicial scrutiny of those laws for compliance with constitutional norms than contemporary plenary power doctrine permits. The Supreme Court has wrongly refused to accord greater scrutiny in such cases. In the few cases in which the Supreme Court has agreed that citizens have standing to challenge immigration law, the Court has asserted that the fact that citizens' rights are at stake is irrelevant to the application of plenary power doctrine. ${ }^{8}$ This judicial conclusion is flawed - or, to be more precise, it is directly contradicted by the rest of the Court's constitutional

5. See infra Part II.A-B.

6. Id.

7. See infra Part II.C.2 (explaining that Shaw v. Reno, 509 U.S. 630 (I993), and its progeny have recognized such an injury).

8. See infra notes 195-204 and accompanying text. Most recently, in Nguyen v. INS, 533 U.S. $53,61,72-73$ (2001), the Court appeared for the first time to reserve the question whether constitutional challenges to immigration policy brought by citizens should be treated any differently than those brought by aliens. Should the Court decide to revisit this question, this Article provides a framework for understanding why its current conclusion is wrong. 
immigration jurisprudence. Courts insulate immigration law from challenge in large part by emphasizing the legal disabilities that American constitutional law imposes on aliens. Citizens do not suffer from these disabilities. Consequently, courts should enforce conventional constitutional norms when citizens challenge immigration policy.

This conclusion does not mean that citizen challenges to immigration law should necessarily be treated exactly like constitutional challenges to domestic law, or that the plenary power doctrine will disappear altogether. There are other reasons why courts may still accord greater deference to the political branches when they review citizen challenges to immigration law. ${ }^{9}$ Nonetheless, reviewing courts will have to scrutinize immigration policy for compliance with conventional constitutional norms.

The application of conventional constitutional norms to immigration law casts serious doubt on the judicial assumption that historical immigration laws, which expressly discriminated on the basis of ethnicity, would be immune to constitutional attack if reenacted today. More importantly, the Article's reorientation of plenary power analysis raises real questions about contemporary immigration policy. Since September 11, 2001, immigration policy has shifted dramatically: there is mounting evidence that the federal government is increasingly relying on race, religion, and ideology in formulating immigration regulations. ${ }^{10}$ While such policies may or may not be constitutional, this Article demonstrates that courts can, and indeed should, subject them to constitutional scrutiny."

\section{I}

\section{The Plenary Power as Standing Doctrine}

The constitutional core of immigration law-the doctrine of Congress's plenary power over immigration-is in large part a doctrine of standing. This fact has gone generally unrecognized. Immigration scholars typically interpret plenary power doctrine as grounded either in the notion that certain constitutional constraints do not operate when Congress exercises its immigration power or in the notion that courts will not enforce those constraints in the context of immigration law. ${ }^{12}$ As this Part shows, however, a third conception of the doctrine operates in constitutional

9. See infra text accompanying notes 205-14.

10. See infra notes 175-79 and accompanying text (discussing several new immigration policies-including the special registration program, the Absconder Initiative, and Operation Liberty Shield-that apply selectively to alicns from certain countries).

11. In arguing that conventional constitutional norms should apply when citizens challenge immigration laws, 1 do not mean to suggest that national security concerns are irrelevant to that constitutional calculus.

12. See, e.g., Neuman, supra note 3, at 14 n.b ("It is unclear whether this doctrine should be considered as denying that constitutional limitations on Congress exist at all, or only as impairing their judicial enforceability."). 
immigration law: courts often implicitly conceptualize the plenary power as grounded in the notion that aliens lack the right to seek meaningful judicial review of the constitutionality of immigration policy.

For over a century, the doctrine of Congress's plenary power over immigration has largely insulated immigration law from constitutional challenge. ${ }^{13}$ Both the substance and scope of this plenary power, as well as the judicial justifications for it, have developed unsteadily and remain incoherent in many respects. ${ }^{14}$ As a result, the power's contours and underpinnings are the subject of substantial doctrinal confusion and extended academic criticism. ${ }^{15}$ In fact, the term "plenary power" itself is an unfortunate and unhelpful phrase. The moniker does not explain what, if anything, is special about constitutional immigration law; Congress's power over many subjects is considered "plenary," but laws concerning other subjects are generally open to constitutional challenge. The term is, if anything, misleading, because it wrongly suggests that the doctrine is concerned solely with congressional "power." As this Part explains, however, the doctrine is far more conceptually complicated and ambiguous. While this complexity and ambiguity make the doctrine difficult to describe with precision, however, it is possible to identify the doctrine's basic thrust: pursuant to the doctrine, courts largely insulate immigration law from constitutional challenges.

\section{A. The Scope of Plenary Power Doctrine}

Before discussing why the plenary power largely shields immigration law from constitutional challenges, it is important to understand what substantive law the plenary power protects. The plenary power is usually said to cover Congress's power over "immigration law." But there is quite a bit of confusion and inconsistency throughout the case law about how to

13. See, e.g., The Chinese Exclusion Case, 130 U.S. 581 (1889); Shaughnessy v. United States ex rel. Mezei, 345 U.S. 206 (1953); Kleindienst v. Mandel, 408 U.S. 753, 769-70 (1972); see also Motomura, Phantom Constitutional Norms, supra note 3, at 550-60 (tracing the history of the plenary power). While the Chinese Exclusion Case is frequently described as the first case to articulate the plenary power, there are precursors to the doctrine. In the Passenger Cases, 48 U.S. (7 How.) 283 (1849), the Supreme Court held unconstitutional two state statutes that taxed the importation of alien passengers on the ground that the statutes interfered with an exclusively federal power. This doctrine was extended in the Head Money Cases, 112 U.S. 580 (1884), in which the Court concluded that the Commerce Clause delegated to the federal government the power to exclude aliens.

14. See, e.g., Neuman, supra note 3 (surveying the constitutional foundations of plenary power doctrine and aliens' rights in the United States).

15. See, e.g., sources cited supra note 3; STEPHEN H. Legomsky, IMmigRation AND THE Judiciary: Law and Politics in Britain and America 172-222 (1987); Louis Henkin, The Constitution and United States Sovereignty: A Century of Chinese Exclusion and Its Progeny, 100 Harv. L. Rev. 853, 885-86 (1987); Hiroshi Motomura, The Curious Evolution of Immigration Law: Procedural Surrogates for Substantive Constitutional Rights, 92 CoLum. L. REv. 1625, 1699. 1704 (1992); Peter H. Schuck, The Transformation of Immigration Law, 84 Colum. L. Rev. 1, 73-90 (1984). 
define the term "immigration law." In this Article, I will generally use this term to refer to the rules governing the exclusion and expulsion of aliens from the United States. ${ }^{16}$ It is with respect to immigration law in this sense that the plenary power most clearly operates. That is not to say that plenary power doctrine does not bleed into jurisprudential arenas that do not seem directly concerned with the exclusion and expulsion of aliens. It does. ${ }^{17}$ Nonetheless, immigration jurisprudence does generally distinguish immigration law thus defined from other laws that regulate aliens' rights and obligations, including their tax status, eligibility for public-sector employment, and entitlement to government benefits. Laws regulating aliens outside the immigration context in these ways typically face greater judicial scrutiny than plenary power doctrine would permit. ${ }^{18}$ More broadly, the plenary power does not protect general domestic legislation-that is, laws that do not directly regulate aliens, in the immigration context or otherwise-from constitutional challenge by aliens. ${ }^{19}$

16. Immigration scholars regularly use this definition. See, e.g., Legomsky, supra note 3, at 256; Motomura, Phantom Constitutional Norms, supra note 3, at 547 \& n.5; Motomura, supra note 15, at 1626. Also, 1 should note that while both plenary power doctrine and this Article typically refer to immigration "law," 1 do not mean to suggest that the doctrine treats federal legislation differently than federal immigration regulations or other legal embodiments of federal immigration policy. But of. Motomura, Phantom Constitutional Norms, supra note 3 (noting that some scholars have argued that courts either do or should distinguish between these different sources of federal immigration policy).

17. See, e.g., Mathews v. Diaz, 426 U.S. 67 (1976) (Medicare eligibility); Soskin v. Reinertson, 257 F. Supp. 2d 1320 (D. Colo. 2003) (Medicaid eligibility), rev'd on other grounds, 353 F.3d 1242 (10th Cir. 2004); $c f$. Zadvydas v. Davis, 533 U.S. 678 (2001).

18. In some contexts the Court subjects laws that regulate noncitizens outside the immigration context to strict scrutiny. See, e.g., In re Griffiths, 413 U.S. 717, 721 (1973); Sugarman v. Dougall, 413 U.S. 634, 642 (1973); Graham v. Richardson, 403 U.S. $365,371-72$ (1971) (holding that alienage is a suspect classification and therefore concluding that certain alienage classifications are subject to strict scrutiny). In other contexts, the Court scrutinizes such laws less closely. See, e.g., Foley v. Connelie, 435 U.S. 291, 295 (1978) (holding that "[i]t would be inappropriate ... to require every statutory exclusion of aliens to clear the high hurdle of 'strict scrutiny'" and upholding, under rational basis review, a state statute excluding aliens from state police force); Diaz, 426 U.S. at 77 (upholding, under rational basis review, federal provision excluding certain lawful permanent residents from eligibility in Medicare); see also Plyler v. Doe, 457 U.S. 202 (1982) (purporting to apply rational basis test to review Texas law that denied undocumented aliens aceess to public education). Even in these latter contexts, however, thc Court scrutinizes the laws more closely than plenary power doctrine would ordinarily permit. Moreover, the Supreme Court has recently reaffirmed that plenary power doctrine applies with less force to laws that regulate aliens outside the immigration context. Compare Zadvydas, 533 U.S. at 695 (invalidating indefinite detention of aliens for whom there is no likelihood of removal, and suggesting that the absence of likely removal makes the detention less immigration-related and thus affects the extent to which plenary power doctrine applies), with Demore v. Hyung Joon Kim, $123 \mathrm{~S}$. Ct. 1708, 1719 (2003) (upholding the mandatory detention of certain aliens pending removal and distinguishing Zadvydas in part on the ground that the aliens in Zadvydas "were ones for whom removal was 'no longer practically attainable' [such] that the detention there did not serve its purported immigration purposc").

19. See Wong Wing v. United States, 163 U.S. 228, 238 (1896) (holding that the Fifth and Sixth Amendments apply to "all persons within the territory of the United States"); Yick Wo v. Hopkins, 118 U.S. 356, 369 (1886) (holding that alien could challenge the constitutionality of a San Francisco laundry ordinance on the ground that the Equal Protection Clause protects all persons within the United States). 
Even with respect to "immigration law," the plenary power is not a monolithic force. For example, the plenary power operates somewhat differently with respect to exclusion and expulsion. ${ }^{20}$ The contours of the doctrine also turn in part on whether substantive or procedural constitutional rights are at stake. ${ }^{21}$ And beyond these limitations, there is a temporal dimension to plenary power doctrine. While early cases sometimes suggested that Congress's immigration power might be entirely insulated from judicial review, more recent case law suggests that limited judicial review is sometimes available. ${ }^{22}$

I should note also that plenary power doctrine does not insulate immigration regulations issued by nonfederal governmental entities. The political branches of the federal government hold the plenary power exclusively. ${ }^{23}$ States do not enjoy such extensive power over immigration law; in fact, courts have historically invalidated state attempts to regulate

20. One of the earliest plenary power cases, Fong Yue Ting v. United States, 149 U.S. 698 (1893), treated exclusion and expulsion indistinguishably. See id. at 707 ("The right of a nation to expel or deport foreigners . . . is as absolute and unqualified as the right to prohibit and prevent their entrance into the country."). Shortly thereafter, however, the Court held that aliens in deportation (or expulsion) proceedings have more rights than those seeking admission to the United States (who are subject to separate exclusion proceedings). See Yamataya v. Fisher, 189 U.S. 86, 100-01 (1903). From that point forward, courts have regularly accorded greater constitutional protection to aliens who have entered the United States. See, e.g., Zadvydas, 533 U.S. at 693 (explaining that the "distinction between an alien who has effected an entry into the United States and one who has never entered runs throughout immigration law"); Shaughnessy v. United States ex rel. Mezei, 345 U.S. 206, 212 (1953) ("It is true that aliens who have once passed through our gates, even illegally, may be expelled only after proceedings conforming to traditional standards of fairness encompassed in due process of law."); Bridges v. Wixon, 326 U.S. 135, 161 (1945) (Murphy, J., concurring) ("The Bill of Rights is a futile autbority for the alien seeking admission for the first time to these shores. But once an alien lawfully enters and resides in this country he becomes invested with [certain] rights . ..."); see also Benitez v. Wallis, 337 F.3d 1289, $1295-1301$ (11 th Cir. 2003); Borrero v. Aljets, 325 F.3d 1003, 1007-08 (8th Cir. 2003); Rios v. INS, 324 F.3d 296, 297 (5th Cir. 2003). Cf. Xi v. INS, 298 F.3d 832, 837-39 (9th Cir. 2002) (refusing on statutory grounds to distinguish between excludable and removable aliens in litigation involving the statutory provision at issue in Zadvydas, but suggesting that Congress could constitutionally amend the provision to do so). While it may seem straightforward to distinguish aliens inside the United States from those outside, it is important to note that the "entry fiction" doctrine in immigration law permits the government to treat some aliens who are physically present in the United States as though they stand at the threshold of entry. See, e.g., Mezei, 345 U.S. at 212-13; Note, Indefinite Detention of Immigrant Parolees: An Unconstitutional Condition?, 116 HaRv. L. Rev. 1868,1868 (2003).

21. For example, the Court has repeatedly held that the Constitution entitles aliens subject to deportation to a deportation hearing that comports with procedural due process. See, e.g., Landon v. Plasencia, 459 U.S. 21, $32-33$ (1982); Wong Yang Sung v. McGrath, 339 U.S. 33, 49-51 (1950); Yamataya, 189 U.S. at 100-01.

22. Compare, e.g., The Chinese Exclusion Case, 130 U.S. 581, 606 (1889), and Ekiu v. United States, 142 U.S. 651, 659-60 (1892), and Lem Moon Sing v. United States, 158 U.S. 538, 547 (1895), with Kleindienst v. Mandel, 408 U.S. 753, 769-70 (1972), and Fiallo v. Bell, 430 U.S. 787, 792 (1977). See also LegomsKy, supra note 15, at 213 ("In the earlier years the Court disavowed in absolute terms any judicial power to review the constitutionality of immigration legislation. The more recent cases, in contrast, contain language that appears to leave the door slightly ajar.").

23. See, e.g., Graham v. Richardson, 403 U.S. 365, 376-78 (1971); Fong Yue Ting, 149 U.S. at 705 (1893). 
immigration. ${ }^{24}$ Between the legislative and executive branches of the federal government, however, there is little discernible difference in the application of plenary power doctrine. While it is typically Congress's power over immigration that courts describe as plenary, ${ }^{25}$ they also regularly invoke plenary power doctrine to insulate executive actions concerning immigration from judicial review. ${ }^{26}$ Although it may be possible to interpret plenary power doctrine as operating differently in the context of congressional and executive action, ${ }^{27}$ courts typically treat the two contexts indistinguishably. ${ }^{28}$

In short, plenary power doctrine most clearly protects the political branches of the federal government in their exercise of power to exclude and expel aliens. Historically, the Supreme Court has invoked the doctrine to reject constitutional challenges to wide-ranging policies, including the statutory exclusion of Chinese nationals; ${ }^{29}$ the indefinite detention, without a hearing, of an alien seeking to enter America, ${ }^{30}$ and the ideological exclusion of scholars. ${ }^{31}$

\section{B. Justifications for Plenary Power Doctrine}

Putting aside the question of what the plenary power covers, there remains the question of why courts have largely insulated immigration law from constitutional challenges. The Supreme Court's plenary power jurisprudence suggests multiple overlapping reasons for shielding federal immigration laws from constitutional challenges. These reasons have been criticized by legal scholars on many grounds. ${ }^{32}$ While I agree with many of the criticisms of the plenary power doctrine, my point in this Article is not to explain why these justifications are wrong or incoherent as a matter of law or morality. Rather, my aim is to show that a more coherent understanding of the conceptual structure of these justifications demonstrates

24. See, e.g., Richardson, 403 U.S. at 376-80; The Passenger Cases, 48 U.S. (7 How.) 283 (1849). It is a separate question, of course, whether the federal government can delegate to the states authority to regulate immigration. See generally Michael J. Wishnie, Laboratories of Bigotry? Devolution of the Immigration Power, Equal Protection, and Federalism, 76 N.Y.U. L. REV. 493 (2001) (arguing that Congress lacks authority to devolve authority over immigration to the states).

25. See, e.g., Fiallo, 430 U.S. at 792 (" "[O]ver no conceivable subject is the legislative power of Congress more complete than it is over' the admission of aliens." (quoting Oceanic Steam Navigation Co. v. Stanahan, 214 U.S. 320,339 (1909))).

26. See, e.g., Mandel, 408 U.S. at 766; Jean v. Nelson, 727 F.2d 957 (11th Cir. 1984) (en banc), aff'd, 472 U.S. 846 (1985).

27. See Motomura, Phantom Constitutional Norms, supra note 3, at 580-83.

28. See cases eited supra note 26.

29. See The Chinese Exclusion Case, 130 U.S. 581, 604-06 (1889).

30. See Shaughnessy v. United States ex rel. Mezei, 345 U.S. 206, 215-16 (1953).

31. See Mandel, 408 U.S. at 766.

32. See, e.g., T. Alexander Aleinikoff, Semblances of Sovereignty: The Constitution, THE State AND American Citizenship 151-81 (2002); T. Alexander Aleinikoff, Federal Regulation of Aliens and the Constitution, 83 AM. J. lNT'L L. 862 (1989); Legomsky, supra note 3; Motomura, Phantom Constitutional Norms, supra note 3. 
that, on its own terms, the plenary power doctrine should not insulate immigration law from constitutional challenges nearly as thoroughly as it currently does. The following discussion shows that the various judicial justifications of the plenary power entail three different conceptions of the doctrine: (1) that it is a doctrine of judicial deference to the political branches; (2) that it is a doctrine concerning the lack of constitutional limits on the political branches' power over immigration; and (3) that it is a standing doctrine. As I argue in Parts II and III, this third judicial conception of plenary power doctrine - that plenary power doctrine is a standing doctrine-has important implications for how the doctrine should operate when citizens' rights are at stake.

To be clear, this typology is not laid out as such in immigration jurisprudence (or scholarship, for that matter). The three conceptions of the plenary power appear together, in a mishmash, throughout the case law. Rarely do courts describe the doctrine purely in terms of just one of the conceptions; instead, they often rely simultaneously on several conceptions of the doctrine to justify the absence of meaningful judicial review. ${ }^{33}$ Worse, courts do not seem to recognize the multiple conceptions of the doctrine at work in the jurisprudence. ${ }^{34}$ To clarify this case law, the discussion below separates out the various judicial conceptions of plenary power doctrine to make clear that it is largely a doctrine of standing.

\section{Judicial Deference}

Courts often conceptualize plenary power doctrine as a doctrine of judicial deference. On this conception, courts refuse to engage in anything more than minimal review of immigration laws for compliance with constitutional norms, choosing instead to defer to Congress's judgment about the constitutional validity of those laws. ${ }^{35}$ This conception of plenary power doctrine does not depend on courts concluding that there are no constitutional constraints on Congress's ability to regulate immigration. Instead, it requires only that courts hold that they are generally not the appropriate institution to evaluate any such constraints. ${ }^{36}$

33. See infra note 209 .

34. See, e.g., Fiallo v. Bell, 430 U.S. 787, 792 (1977) (alluding to all three conceptual bases without suggesting that they constitute distinct justifications for the plenary power).

35. See, e.g., id.; Ekiu v. United States, 142 U.S. 651, $659-60$ (1892); The Chinese Exclusion Case, 130 U.S. 581, 606-09 (1889). As Justice Frankfurter explained in Harisiades v. Shaughnessy, 342 U.S. 580 (1952):

Though as a matter of politieal outlook and economic need this country has traditionally welcomed aliens to come to its shores, it has done so exclusively as a matter of political outlook and national self-interest. This policy has been a political policy, belonging to the political branch of the Government wholly outside the concern and the competence of the Judiciary.

Id. at 596 (Frankfurter, J., concurring).

36. See, e.g., Fiallo, 430 U.S. at 792; Harisiades, 342 U.S. at 596-97 (Frankfurter, J., concurring); The Chinese Exclusion Case, 130 U.S. at 609. 
Understood as a doctrine of judicial deference, the plenary power is a close cousin of the political question doctrine. Under the classic formulation of the political question doctrine, courts decline to review a congressional or executive decision either because the constitution has demonstrably committed authority to make that decision to another branch of government, or because there are no determinable standards that would enable the court to engage in judicial review. ${ }^{37}$ Plenary power doctrine often employs a similar vocabulary. On this account, the doctrine reflects the fact that the Constitution vests exclusive authority to make immigration decisions in the hands of the political branches of the federal government. ${ }^{38}$ Some cases suggest this indirectly, indicating that congressional decisions concerning immigration are conclusive on the courts. ${ }^{39}$ Other cases make more explicit the connection with the political question doctrine. In Fong Yue Ting, for example, the Court stated that "it behooves the court to be careful that it does not undertake to pass upon political questions, the final decision of which has been committed by the Constitution to the other departments of the government." 40

Despite its close connection to the political question doctrine, there is an important distinction between the political question doctrine and this flavor of plenary power jurisprudence. Under the political question doctrine, courts categorically refuse to engage in any judicial review of political questions. ${ }^{41}$ At least as a matter of contemporary plenary power jurisprudence, however, limited review of immigration law is at least

37. See, e.g., Baker v. Carr, 369 U.S. 186, 210-11 (1962). See generally Rachel E. Barkow, More Supreme than Court? The Fall of the Political Question Doctrine and the Rise of Judicial Supremacy, 102 Colum. L. REv. 237 (2002) (discussing the constitutional and prudential bases of classical political question doctrine).

38. Ekiu, 142 U.S. at 659 "[The immigration] power is vested in the national government, to which the constitution has committed the entire control of international relations .... [T] has conferred [on Congress] power to regulate commerce with foreign nations [and] to establish a uniform rule of naturalization .....); accord Fong Yue Ting v. United States, 149 U.S. 698, 705, 711 12 (1893).

39. See The Chinese Exclusion Case, 130 U.S. at 604-06 (suggesting that Congress's exercise of power was restricted "by the constitution itself and considerations of public policy and justice," but holding that Congress's determination that the exclusion was justified was "conclusive upon the judiciary"); Klcindienst v. Mandel, 408 U.S. 753, 768-69 (1972); Harisiades, 342 U.S. at 589-90; Knauff v. Shaughnessy, 338 U.S. 537, 543 (1950).

40. 149 U.S. at 712 (emphasis added); see also Mathews v. Diaz, 426 U.S. 67, $81-82$ (1976) ("The reasons that preclude judicial review of political questions also dictate a narrow standard of review of decisions made by the Congress or the President in the area of immigration and naturalization." (citation omitted)). As a historical matter, the political question basis for the plenary power shares intellectual roots with foreign affairs jurisprudence, in which courts have frequently invoked the political question doctrine. See, e.g., United States v. Curtiss-Wright Exp. Corp., 299 U.S. 304, 319-22 (1936); cf. Harisiades, 342 U.S. at 588-89 ("[A]ny policy toward aliens is vitally and intricately interwoven with contemporaneous policies in regard to the conduct of foreign relations, the war power, and the maintenance of a republican form of government.").

41. See, e.g., Colegrove v. Green, 328 U.S. 549, 552-56 (1946) (holding nonjusticiable a constitutional challenge to Illinois's congressional redistricting). 
formally available. ${ }^{42}$ For that reason, it is more accurate under this conception to describe plenary power doctrine as a doctrine of judicial deference than to describe it as a doctrine of nonjusticiability. ${ }^{43}$

\section{Unlimited Congressional Power}

Courts also understand plenary power doctrine to reflect the lack of any constitutional limitations on Congress's exercise of its immigration power. While the judicial deference conception of plenary power doctrine concerns only which institution should judge the validity of federal immigration regulation, the second conception focuses on the substantive constitutional limits that restrict Congress's exercise of its immigration power. On this second judicial conception of the plenary power, Congress's power over immigration is simply unlimited by any constitutional constraints. ${ }^{44}$

This conception of plenary power doctrine is perhaps linguistically most closely connected to the description of the immigration power as "plenary." 45 Language aside, however, this description of the plenary power invites the question of why there would be no constitutional constraints on Congress's exercise of immigration power. Plenary power case law suggests at least two different sources of this unlimited power. First, courts sometimes suggest that the font of the power is extraconstitutionalthat sovereignty inherently entails unlimited power over immigration or that international law grants such power to all sovereign nations. ${ }^{46}$ Because

42. See, e.g., Fiallo v. Bell, 430 U.S. 787, 793 (1977) (noting "the need for special judicial deference to congressional policy choices in the immigration context"); Mathews v. Diaz, 426 U.S. 67 , 82 (1976) (noting the "narrow standard of review of [immigration] decisions"). While it is clear that narrow review is formally available today, early plenary power cases do hint at the more categorical denial of review that typically accompanies the judicial determination that a controversy presents a nonjusticiable political question. See supra text accompanying note 40; see also LEGoMsKY, supra note 15, at 213 (noting this change); AleinikofF, supra note 32, at 155 (same).

43. Again, 1 do not mean to imply that the political question flavor of the plenary power doctrine (or any other account, for that matter) is justifiable. The political question doctrine in general has been widely eriticized. See, e.g., Martin H. Redish, Judicial Review and the "Political Question," 79 Nw. U. L. REv. 1031, 1060 (1984-85). See generally Barkow, supra note 37. Moreover, the Court has, over time, pared back the doctrine in many other contexts. See, e.g., Baker v. Carr, 369 U.S. 186 (1962) (holding justiciable constitutional challenges to legislative redistricting, which a plurality of the Court had previously concluded, in Colegrove v. Green, 328 U.S. 549 (1946), presented nonjusticiable political questions). In light of the fact that doctrines of nonjusticiability are on the wane in other areas of law, it is worth asking why the plenary power's closely related doctrine of deference retains its force. See AlEINIKoFf, supra note 32, at 164-65.

44. See, e.g., Fong Yue Ting, 149 U.S. at 705; The Chinese Exclusion Case, 130 U.S. 581, 60304 (1889).

45. The Oxford English Dictionary defines "plenary" as "eomplete, entire, perfect, not deficient in any element or respect... absolute, unqualified: as plenary indulgence, power, remission." XI Oxford ENGLish Dictionary 1039 (2d ed. 1989).

46. See, e.g., The Chinese Exclusion Case, 130 U.S. at 603-04 (suggesting that the power is inherent in the sovereignty of every nation); Ekiu v. United States, 142 U.S. 651, 659 (1892) (suggesting that the power derives from international law); Knauff v. Shaughnessy, 338 U.S. 537, 542 (1950) ("The exclusion of aliens is a fundamental act of sovereignty."). 
the power is extraconstitutional, courts conclude that the power is not subject to any constitutional constraints. ${ }^{47}$ Second, courts (sometimes the same courts) on occasion indicate that the Constitution itself delegates to Congress unlimited power over immigration, either through the provisions related to foreign affairs or through some other constitutional source. ${ }^{48}$

Both the extraconstitutional and constitutional justifications for unlimited congressional power over immigration are in some tension with American constitutional traditions. The extraconstitutional justification is problematic because the federal government is typically understood to have no more power than that given by the Constitution. ${ }^{49}$ The notion that a federal power can derive from another source or be inherent in sovereignty is at odds with this tradition. ${ }^{50}$ Relatedly, the constitutional justification runs into trouble because all of the federal government's enumerated constitutional powers are generally thought to be limited by various constitutional

47. See, e.g., Jean v. Nelson, 727 F.2d 957, 964 n.5 (1 l th Cir. 1984) (en banc) ("Because this 'undefined and undefinable' sovereign power does not depend on any constitutional grant of authority, there are apparently no limitations on the power of [admission] ... . Aliens may therefore be denied admission on grounds that would be constitutionally impermissible or suspect in the context of domestic legislation."), aff'd, 472 U.S. 846 (1985). Note that, even if it is correct to conclude that the political branch's power over immigration is inherent in sovereignty, it does not necessarily follow that there can be no constitutional limitations on that power. See LEGOMSKY, supra note 15, at 320.

48. See, e.g., Knauff, 338 U.S. at 542 (noting that "the right [to exclude aliens] stems not alone from legislative power but is inherent in the executive power to control the foreign affairs of the nation," and citing a discussion in Fong Yue Ting, 149 U.S. at 713, about Congress's exercise of its constitutionally delegated powers); Fong Yue Ting, 149 U.S. at 705 (stating that the immigration power "is vested in the national government, to which the constitution has committed the entire control of international relations"); The Chinese Exclusion Case, 130 U.S. at 609 (stating that the power over immigration is "delegated by the constitution"). On occasion, the Supreme Court has blended the extraconstitutional and constitutional sources together, arguing that the unlimited power over immigration that is an incident of sovereignty passed to the federal government through the Constitution (though not through any specific provision of the Constitution). Id. ("The power of exclusion of foreigners [is] an incident of sovereignty belonging to the government of the United States as part of those sovereign powers delegated by the constitution ....").

49. See, e.g., The Federalist Nos. 41-45 (James Madison) (discussing the limited, enumerated powers that the proposed Constitution would confer on the national government); Ex parte Quirin, 317 U.S. 1, 25 (1942) ("Congress and the President, like the courts, possess no power not derived from the Constitution."); McCulloch v. Maryland, 17 U.S. (4 Wheat.) 316, 405 (1819) ("This government is acknowledged by all, to be one of enumerated powers. The principle, that it can exercise only the powers granted to it ... is now universally admitted.").

50. Nonetheless, the plenary power doctrine is not the only doctrine that trades on somewhat extraconstitutional bases of federal authority. A similar strain of extraconstitutional argument runs through much of foreign affairs jurisprudence. See, e.g., United States v. Curtiss-Wright Exp. Corp., 299 U.S. 304, 318 (1936) ("The power to acquire territory . . , the power to expel undesirable aliens, the power to make such international agreements as do not constitute treaties in the constitutional sense, none of which is expressly affirmed by the Constitution, nevertheless exist as inherently inseparable from the conception of nationality." (citations omitted)). See generally Sarah H. Cleveland, Powers Inherent in Sovereignty: Indians, Aliens. Territories, and the Nineteenth Century Origins of Plenary Power over Foreign Affairs, 81 TEx. L. REv. 1 (2002). Sovereign immunity jurisprudence also employs somewhat extraconstitutional arguments. See, e.g., Alden v. Maine, 527 U.S. 706 (1999). 
constraints. ${ }^{51}$ For instance, to acknowledge that Congress's power over interstate commerce is "plenary" is not to conclude that the power is subject to no constitutional limitations: both structural constitutional concerns (e.g., separation of powers and federalism) and individual rights (e.g., equal protection and due process) limit Congress's commerce power. ${ }^{52}$ It is difficult to understand why a delegated plenary power over immigration would be any different. Despite the lack of a justification for unlimited congressional power over immigration that makes sense in light of our constitutional structure, however, the first plenary power cases conceptualized the power in just this way. ${ }^{53}$ While courts rely on this conception much less today, and while the Supreme Court has recently hinted at its potential demise, ${ }^{54}$ courts on occasion continue to suggest that there are simply no, or very few, constitutional limitations on Congress's power over immigration. ${ }^{55}$

\section{Alien Standing}

Courts also implement plenary power doctrine as a standing doctrine. On this conception, which is generally unrecognized, courts largely insulate immigration laws from constitutional attack by aliens on the ground that they do not have the right to seek judicial review of those laws. ${ }^{56}$

51. For example, the Bill of Rights provides a number of such constraints. See, e.g., U.S. Const. amend. I ("Congress shall make no law respecting an establishment of religion . . ..").

52. See, e.g., Gibbons v. Ogden, 22 U.S. (9 Wheat.) 1, 196 (1824) ("[The commerce] power, like all others vested in Congress, is complete in itself, may be exercised to its utmost extent, and acknowledges no limitations, other than are prescribed in the constitution." (emphasis added)). I distinguish between structural and individual rights-based limitations because much constitutional law does so. I do not mean to suggest that, as a matter of constitutional theory, there should necessarily be a difference between these different types of constitutional limitations on the government's exercise of power.

53. See cases cited supra notes 41,44 .

54. See Zadvydas v. Davis, 533 U.S. 678, 695 (2001) (emphasizing that even the plenary power "is subject to important constitutional limitations").

55. See, e.g., Benitez v. Wallis, 337 F.3d 1289, 1296-98 (1 1 th Cir. 2003); Borrero v. Aljets, 325 F.3d 1003, 1007-08 (8th Cir. 2003); Rios v. INS, 324 F.3d 296, 297 (5th Cir. 2003); see also Fiallo v. Bell, 430 U.S. 787, 792 (1977) (citing Shaughnessy v. United States ex rel. Mezei, 345 U.S. 206, 210 (1953), for the proposition that Supreme Court case law has "long recognized the power to expel or exclude aliens as a fundamental sovereign attribute"); Jean v. Nelson, 727 F.2d 957, 964 n.5 (1 1 th Cir. 1974) (en banc) (concluding that "there are apparently no limitations on the power of the federal government to determine what classes of aliens will be permitted to enter the United States"), aff' $d, 472$ U.S. 846 (1985).

56. See Allende v. Shultz, 845 F.2d 1111, 1114 n.4 (1st Cir. 1988) (stating that Kleindienst v. Mandel, 408 U.S. 573 (1972), "established that an alien has no standing to bring a constitutional challenge to the denial of a visa, and that in a suit contesting such a denial, the inclusion of an alien as a party is purely symbolic"); Romero v. Consulate of U.S., Barranquilla, Colom., 860 F. Supp. 319, 323 n.7 (E.D. Va. 1994) ("[A]n unadmitted offshore alien [has] no constitutional right of entry to this country as a nonimmigrant or otherwise. Here, plaintiffs are unadmitted offshore aliens who ... have no standing to challenge the denial of their entry." (internal quotation marks and citation omitted)); Allende v. Shultz, 605 F. Supp. 1220, 1222 n.1 (D. Mass. 1985); Chinese Am. Civic Council v. Attorney General, 396 F. Supp. 1250, 1251 (D.D.C. 1975) ("Standing apparently has never been 
Aliens lack the capacity to seek sueh review because they lack enforceable rights with respect to immigration law. ${ }^{57}$ Unlike the second conception of plenary power doctrine, this conception does not turn on the existence of a substantive constitutional norm reflecting a general immunity of immigration law from constitutional or other constraints. Rather, the standing conception of the doctrine-perhaps the most prevalent (though unnoticed) conception in the case law-is much more limited. On this conception, a lack of enforceable rights by aliens, rather than a more general immunity from constitutional constraints, drives the judicial insulation of immigration law.

Often, courts cast aliens' lack of a right to judicial review expressly in standing terms. ${ }^{58}$ This formulation is most typical in cases involving an alien outside the country who is seeking entry. ${ }^{59}$ Even in cases that do not expressly invoke the term "standing" to insulate immigration law from constitutional challenges by aliens, courts still regularly rely on the logic of standing, coneluding that aliens lack the right to seek judicial review of the constitutionality of immigration law. ${ }^{60}$ It is this reasoning, for example, that echoes in the oft-repeated judicial assertion that Congress, in the process of regulating immigration law, can do things to aliens that would be unacceptable if done to citizens. ${ }^{61}$

This does not mean that plenary power jurisprudence suggests that immigration law never injures aliens. Obviously, immigration law affects the interests of, and can injure, aliens when it excludes them, deports them,

granted to a person outside the United States challenging the denial of entry or immigration eligibility."), aff'd, 566 F.2d 321 (D.C. Cir. 1977).

57. See, e.g., Landon v. Plasencia, 459 U.S. 21, 32 (1982) ("[A]n alien seeking initial admission to the United States requests a privilege and has no eonstitutional rights regarding his application...."); Mandel, 408 U.S. at 762 ("It is clear that Mandel personally, as an unadmitted and nonresident alien, had no eonstitutional right of entry to this country as a nonimmigrant or otherwise."); Adams v. Baker, 909 F.2d 643, 647 n.3 (Ist Cir. 1990) (stating that alien has no constitutional rights with respect to entry and no standing to seek judicial review of visa denial); Jean, 727 F.2d at 968 ("Aliens seeking admission to the United States ... have no constitutional rights with regard to their applications...."). Sometimes, the Court suggests only that aliens lack constitutional rights with respeet to their entry into the United States. Frequently, however, courts suggest that aliens lack constitutional rights (or have fewer, or somehow less powerful, constitutional rights) with respect to much more than their entry into and presence in the United States. See, e.g., Miller v. Albright, 523 U.S. 420, 451 (1998) (O'Connor, concurring in the judgment) (" 11$]$ t is unclear whether an alien may assert constitutional objections when he or she is outside the territory of the United States ...."); United States v. Verdugo-Urquidez, 494 U.S. 259, $271-75$ (1990) (suggesting that aliens may not receive any constitutional protection until they have come within the territory of the United States); Johnson v. Eisentrager, 339 U.S. 763, 777-78 (1950) (same).

58. See cases eited supra note 56.

59. $l d$.

60. See, e.g., Reno v. Am.-Arab Anti-Discrimination Comm., 525 U.S. 471, 488 (1999); Mandel, 408 U.S. at 762; Mezei, 345 U.S. at 212-14. In some cases, courts hold that aliens' constitutional right of action is extremely limited, rather than entirely nonexistent. See, e.g., Landon v. Plasencia, 459 U.S. 21, 32 (1932); Yamataya v. Fisher, 189 U.S. 86, 100-01 (1903).

61. Mathews v. Diaz, 426 U.S. $67,79-80$ (1976). 
or otherwise makes them the subjects of regulation. Rather, plenary power case law frequently concludes that, because aliens lack enforceable rights with respect to immigration law, the injuries aliens suffer are not judicially cognizable. Denying aliens standing despite the fact that they clearly are injured might at first seem odd, given that standing law's core requirement is that a plaintiff demonstrate an "injury in fact." 62 But as commentators have frequently explained and the Supreme Court has increasingly acknowledged, the existence of a cognizable injury is inevitably the product of legal conventions: injuries are cognizable only when some source of law treats the injury as sufficient to confer on the injured party the right to bring suit. ${ }^{63}$ Injuries to aliens that stem from immigration law are not considered cognizable because courts have concluded, pursuant to the plenary power doctrine, that aliens lack the constitutional rights with respect to immigration law that would be necessary for their injuries to be cognizable. $^{64}$

62. See, e.g., Friends of the Earth, Inc. v. Laidlaw Envtl. Servs., 528 U.S. 167, 180 (2000) ("In Lujan v. Defenders of Wildlife [504 U.S. 555, 560-61 (1992)], we held that, to satisfy Article lll's standing requirements, a plaintiff must show (I) it has suffered an 'injury in fact' ...."); Ass'n of Data Processing Orgs. v. Camp, 397 U.S. 150, 152 (1970) ("The first question is whether the plaintiff alleges that the chailenged action has caused him injury in fact ....").

63. See, e.g, FEC v. Akins, 524 U.S. 11, 22 (1998); Warth v. Seldin, 422 U.S. 490, 500 (1975) (noting that standing turns on "whether the constitutional or statutory provision on which the claim rests properly can be understood as granting persons in the plaintiff's position a right to judicial relief'); Lee Albert, Standing to Challenge Administrative Action: An Inadequate Surrogate for Claim for Relief, 83 YALE L.J. 425, 425-29 (1974); David P. Currie, Misunderstanding Standing, 1981 SuP. CT. REv. 41, 41-43; William A. Fletcher, The Structure of Standing, 98 YALE L.J. 221, 248-49 (1988) ("In the legal system, injury is assessed against the normative structure provided by the particular legal rights. . . A plaintiff has standing only if she can show that she is entitled to sue under the particular statutory or constitutional provision at issue."); Cass R. Sunstein, Informational Regulation and Informational Standing: Akins and Beyond, 147 U. PA. L. Rev. 613, 640 (1999) [hereinafter Sunstein, Informational Standing] ("The legal system does not 'see' an injury unless some law has made it qualify as such. If this point seems obscure, it is only because of widespread agreement, within the legal culture, about which injuries are 'injuries in fact' and which are not. But the agreement comes from understandings of law, not understandings of fact."); Cass R. Sunstein, What's Standing After Lujan? Of Citizen Suits, "Injuries," and Article III, 91 MiCH. L. REv. 163, 190 (1992) [hereinafter Sunstein, Standing After Lujan] ("[W]hether there is a so-called nonjusticiable ideological interest, or instead a legally cognizable 'actual injury,' is a product of legal conventions and nothing else.").

64. The ideological exclusion cases highlight the close connection between standing and rights. Those cases repeatedly hold that the excluded alien lacks standing to raise constitutionai claims, while the citizens who invited the alien have such standing. See infra Part 11.A. This is not because the alien is not injured in any way by the exclusion. Rather, it is because the alien lacks enforceable rights in this context. See, e.g., Allende v. Shultz, 845 F.2d 1111 , 1114 n.4 (Ist Cir. 1998) ("Kleindienst v. Mandel established that an alien has no standing to bring a constitutional challenge to the denial of a visa .... The Court stated: 'It is clear that [the applicant] personally, as an unadmitted and nonresident alien, had no constitutional right of entry to this country..." (citation omitted) (second alteration in original)); cf. Haitian Refugee Ctr. v. Gracey, 809 F.2d 794, 800 (D.C. Cir. 1987). Justice O'Connor's concurring opinion in Miller v. Albright, 523 U.S. 420 (1998), similarly illustrates the close connection between constitutional rights and standing to sue. Miller concemed a claim by a daughter that a federal naturalization provision discriminated against her father on the basis of sex, in violation of the Equal Protection Clause. Justice O'Connor agreed that the daughter was "clearly injured by the fact that she has been denied citizenship," $i d$. at 446 , but concluded that she could not raise the equal protection 
The Supreme Court has suggested several reasons why aliens lack the right to raise constitutional challenges to federal immigration laws. The Court sometimes suggests that aliens lack such a right because of territorial limits on the power of the Constitution. ${ }^{65}$ The Court also often describes the limitation in membership terms: aliens, the Court suggests, are not full members of our political community and, as a result, are sometimes not entitled to the full protection of the Constitution. ${ }^{66}$ Frequently, the Court blurs together the territorial and membership lines of reasoning. As many commentators have pointed out, these justifications fit at best imperfectly with the contemporary scope of the plenary power. ${ }^{67}$ Nonetheless, the standing conception carries substantial weight in cases concerning the power. Consequently, plenary power doctrine is often implicitly understood to reflect a legal disability on the part of aliens, rather than a more general exemption of immigration policy from legal constraints.

In short, the plenary power doctrine is principally a doctrine of standing. Seen in this light, Congress's plenary power over immigration is not really "plenary" in the conventional sense. The political branches' immigration power is not, on this understanding, limitless and unconstrained by any constitutional duties. Rather, immigration law is largely insulated from constitutional challenges by aliens because they lack the right to bring such claims.

claim because she did not have a legally protectable interest with respect to the discrimination against her father. She was not "within the class of persons with respect to whom the act is unconstitutional." Id. (O'Connor, J., concurring in the judgment) (quoting Heald v. District of Columbia, 259 U.S. 114, $123(1922))$.

Outside the immigration context, Second Amendment jurisprudence provides another good example of the connection between constitutional rights and constitutional standing. The foundational question in Second Amendment cases is whether the Amendment confers a constitutional right on individuals. Courts that conclude that there is no individual right frequently dismiss for lack of standing. See, e.g., Silveira v. Lockyer, 312 F.3d 1052, 1066 n. 17 (9th Cir. 2002) ("We concluded in Hickman that because the individual plaintiff had no legally protectable interest under the Second Amendment, he lacked constitutional standing to bring a claim under that provision. ... [T] of an individually enforceable Second Amendment right resulted in a lack of standing ....").

65. See United States v. Verdugo-Urquidez, 494 U.S. 259, 269 (1990) (suggesting a strongly territorial version of constitutional protection); Shaughnessy v. United States ex rel. Mezei, 345 U.S. 206, 212 (1953); Johnson v. Eisentrager, 339 U.S. 763, 784 (1950) (holding that aliens outside the territory of the United States lack Fifth Amendment rights). The territorial distinction may be gaining some purchase on the Supremc Court. See Zadvydas v. Davis, 533 U.S. 678, 693 (2001).

66. See, e.g., Verdugo-Urquidez, 494 U.S. at 265 (suggesting that aliens lack certain constitutional protections because they are not part of the "national community"); see also NeUmaN, supra note 3, at 53-63; T. Alexander Aleinikoff, Citizens, Aliens, Membership and the Constitution, 7 Const. Comment. 9, 9-20 (1990). See generally David A. Martin, Graduated Application of Constitutional Protections for Aliens: The Real Meaning of Zadvydas v. Davis, 2001 SuP. CT. REv. 47.

67. See, e.g., Neuman, supra note 3, at 72-73. 
Where a party does have constitutional standing to challenge an immigration law, the standing conception does not justify insulating that law from review. As Part III explains, the absence of the standing-based justification in such cases undermines the foundation of the plenary power doctrine. Before turning in Part III to the ways in which the presence of a party with constitutional standing to challenge immigration law undermines plenary power doctrine, however, I first address, in Part II, the question whether someone other than the aliens directly regulated by such laws ever has standing to raise a constitutional challenge.

II

\section{Citizen Injuries and Citizen Standing}

Citizens should have standing to challenge immigration policy in many circumstances. Yet neither courts nor commentators commonly consider the possibility of citizen standing to challenge immigration laws. The reason is unsurprising - and closely related to the reason that aliens lack standing. Aliens lack standing because in many circumstances they lack legal rights to assert with respect to immigration laws. ${ }^{68}$ Unlike aliens, citizens do not suffer from this disability: citizens are full members of the constitutional community, and they consequently have many constitutional and statutory rights that aliens lack. Yet it is precisely citizens' full membership that is thought to deprive them of standing to challenge immigration laws. Standing doctrine's core requirement is that one assert a cognizable injury, and it is easy to conclude that citizens cannot be injured in any cognizable way by immigration laws because they already enjoy the entitlement of residence and the benefits of citizenship.

As this Part demonstrates, however, that conventional wisdom is mistaken. Immigration laws regularly injure citizens in legally cognizable ways. Parts II.A and II.B show that the Supreme Court and lower courts have sporadically acknowledged this, albeit without recognizing the full implications of citizen standing. Courts have recognized on occasion, for example, that immigration law can impinge on citizens' assoeiational and economic interests in ways that uncontroversially satisfy Article III's standing requirements. ${ }^{69}$ But courts have not recognized such injuries consistently. Moreover, as Part II.C argues, citizen standing should sweep more broadly than the recognition of associational or economic injuries would suggest. Immigration law plays a central role in national selfdefinition, and it may injure citizens by expressing constitutionally impermissible notions of national political identity. While courts have never considered this possibility, parallels in voting rights jurisprudence suggest that such an injury can be legally cognizable.

68. See supra text accompanying notes 62-67.

69. See cases cited infra Parts II.A-B. 


\section{A. Associational Injuries}

Immigration law regularly injures citizens by expelling or excluding people with whom citizens wish to associate. When a person is excluded or expelled from the country pursuant to immigration policy, citizens who desire to associate with that person are denied the opportunity to do so, unless they are willing to incur the expense and undertake the time required to travel abroad to see the person. Courts have frequently acknowledged that such associational injuries can be legally cognizable.

The potential separation of family members by immigration policy presents perhaps the paradigmatic example of this associational injury. Courts have held that such an injury can be legally cognizable. ${ }^{70}$ In Fiallo $v$. Bell, for example, the Supreme Court accorded standing to citizen and resident alien fathers who challenged an immigration provision that excluded their children on grounds that arguably interfered with their constitutional rights to both equal protection and familial association. ${ }^{71}$ And in Nguyen $v$. INS, the Court held that citizen fathers had standing to challenge an immigration statute that implicated their children's ability to enter or remain in the United States and that arguably infringed the equal protection rights of the citizen fathers. ${ }^{72}$

Even when the potential immigrant is not a family member, courts have concluded that immigration law's interference with these associational interests can constitute a cognizable injury. For example, courts have regularly held that citizens who invite a foreign speaker to America have standing to assert both First Amendment and statutory challenges to the speaker's exclusion from the country. ${ }^{73}$ Immigration law's interference

70. See sources eited infra notes 71-72; see also Legal Assistance for Vietnamese Asylum Seekers v. Dep't of State, 45 F.3d 469, 471 (D.C. Cir. 1995) ("First, as to injury in fact, the State Department's conduct prolongs the separation of immediate family members. ... We have previously found injury in fact where the plaintiffs were far less aggrieved than in the case at bar."), vacated on other grounds, 519 U.S. 1 (1996). Relatedly, a citizen infant or child might be eognizably injured by her parents' exclusion or expulsion from the eountry. See Acosta v. Gaffney, 558 F.2d 1153, 1156-57 (3d Cir. 1977) (holding that infant citizen had standing to challenge denial of stay of deportation for her parents on the ground that their deportation would deprive her of her constitutional right to reside in the United States because, as an infant, she must remain with her parents).

71. 430 U.S. 787, 790 (1977); see also id. at 795 n.6 (acknowledging "the impact of these classifieations on the interests of those already within our borders").

72. 533 U.S. 53, $58(2001)$.

73. See Kleindienst v. Mandel, 408 U.S. 753, 759, 762 (1972); Adams v. Baker, 909 F.2d 643, 647 \& n.3 (lst Cir. 1990); Allende v. Shultz, 845 F.2d 1111, 1114 \& n.4 (1st Cir. 1988); Abourezk v. Reagan, 785 F.2d 1043, 1050-51 (D.C. Cir. 1986) (holding that citizens who invited foreign speaker have standing to seek review of visa denial because they " $[\mathrm{u}]$ nquestionably . . . are 'aggrieved' by the State Department's resort to section 1182(a)(27) to keep out people they have invited to engage in open discourse with them within the United States"), aff' $d$ by an equally divided Court, 484 U.S. 1 (1987); Harvard Law Sch. Forum v. Shultz, 633 F. Supp. 525, 529 (D. Mass. 1986), vacated, 852 F.2d 563 (1st Cir. 1986) (unpublished table decision). 
with the relationship between an employer and an employee (or potential employee) has similarly been considered a cognizable injury. ${ }^{74}$

Unsurprisingly, courts are reluctant to extend the scope of cognizable associational injuries to include claims relating to the desire to associate with large undifferentiated classes of potential immigrants. ${ }^{75}$ If the injury were judicially cognizable in all such cases, citizens would have standing to challenge any immigration policy on the ground that immigration rules, by definition, implicate the interests of citizens in associating freely with some group of people who are the subjects of those rules. For that reason, courts have suggested that associational injuries may not be cognizable where they do not relate to identifiable persons who are deported or excluded by immigration law. ${ }^{76}$ This caveat aside, however, associational interests represent one well-established interest of American citizens that immigration policy can affect in legally cognizable ways.

\section{B. Economic Injuries}

Citizens can also suffer cognizable economic injuries at the hands of immigration policy. Consider, for example, employment situations. If the United States excludes or deports an employee, her employer suffers an economic injury that courts have recognized as sufficient to confer standing in certain circumstances. ${ }^{77}$ Thus, for example, the D.C. Circuit has held that prospective employers have standing to challenge denials of labor certification for alien-employees. ${ }^{78}$

74. See, e.g., Pesikoff v. Sec'y of Labor, 501 F.2d 757, 760-61 (D.C. Cir. 1974) (holding that putative employer had standing to seek APA review of denial of labor certification for alien). As the next section makes clear, this injury can be conceptualized as economic as well as associational. See infra Part Il.B.

75. See Haitian Refugee Ctr. v. Gracey, 809 F.2d 794, 800 (D.C. Cir. 1987) ("[The plaintiffs'] claim is merely that they have been deprived of an opportunity to associate with some number of a class of unidentified aliens seeking to enter the country.... It is unclear whether an injury so generalized and unspecific is adequate for standing purposes."); Am. Immigration Lawyers Ass'n v. Reno, 18 F. Supp. 2d 38, 49-50 (D.D.C. 1998) (holding that AlLA lacked standing to challenge expedited removal procedures that might deprive them of contact with aliens who could be potential clients), aff'd on other grounds, 199 F.3d 1352 (D.C. Cir. 2000).

76. See Haitian Refugee Ctr., 809 F.2d at 800 (questioning whether associational injury was sufficient to confer standing where "[a]ppellants do not assert that they have been deprived of an opportunity to meet with a particular alien concerning a particular subject," but instead "claim ... merely that they have been deprived of an opportunity to associate with some number of a class of unidentified aliens seeking to enter the country"); Am. Immigration Lawyers Ass ' $n$, 18 F. Supp. $2 \mathrm{~d}$ at 49 .

77. See, e.g., Pesikoff, 501 F.2d at 760-61 (granting standing to the prospective employer of an alien to challenge the Labor Department's refusal to issue an immigration labor certification to that alien).

78. See id.; Sec'y of Labor v. Farino, 490 F.2d 885, 889 (7th Cir. 1973) ("It is clear that these [employers] have adequately alleged that they will be eeonomically injured if not permitted to employ these aliens."); $c f$. First Girl, Inc. v. Reg'l Manpower Adm'r, 499 F.2d 122, 124 (7th Cir. 1974) (granting standing, sub silentio, to prospective employer to challenge denial of labor certification). 
As standing jurisprudence has made clear, economic injuries can be cognizablc even where they are not tied to a single transaction or even to an express economic relationship between two parties. Courts commonly recognize that a person can be affected by the aggregate economic (or other) effects of private actions or a regulatory scheme, and such effects frequently satisfy the requirements of constitutional standing. ${ }^{79}$ Thus, even where citizen employers are not seeking to have a particular employee or potential employee admitted to the country, they may be injured in legally cognizable ways by immigration law. For example, an immigration policy that excludes certain skilled immigrants could injure some employers by forcing them to pay higher wages, placing them at a competitive disadvantage relative to firms willing to employ undocumented workers. ${ }^{80}$ Conversely, citizen employees may suffer cognizable economic injuries where immigration policies allow large numbers of immigrants into the countryparticularly if those immigrants are undocumented. ${ }^{81}$ At least one court has upheld citizen standing on just this ground: Northwest Forest Workers Ass' $n v$. Lyng held that workers concerned about the economic effects of regulations implementing a guest worker program had standing to challenge those regulations. ${ }^{82}$

Economic injuries need not be limited to the employment context. If the United States were to adopt a particularly lenient immigration policy that admitted a flood of immigrants, for example, that policy could produce measurable economic impacts on the communities into which those immigrants are introduced. ${ }^{83}$ Under such circumstances, citizens might have

79. See, e.g., Friends of the Earth v. Laidlaw Envtl. Servs., 528 U.S. 167, 169 (2000) (finding that environmental plaintiffs had satisfied the injury in fact requirement where they argued that Laidlaw's repeated mercury discharges would affect their recreational, aesthetic, and eeonomic interests); United States v. Students Challenging Regulatory Agency Procedures (SCRAP), 412 U.S. $669,687-90$ (1973) (finding that plaintiffs had satisfied the injury in fact requirement where they argued that the adverse environmental effects of a railroad freight price regulation would interfere with their enjoyment of outdoor spaces in the Washington metropolitan area).

80. Cf. Brief of Amici Curiae American Civil Liberties Union Foundation \& Make the Road by Walking, Inc., Hoffman Plastic Compounds, Inc. v. NLRB, 535 U.S. 137 (2002) (No. 00-1595) (discussing the ineentives of employers to hire undoeumented workers, as well as how immigration policy can affect those incentives).

81. See, e.g., Select Commission on lmmigration and Reform Policy, 97th Cong., U.S. 1mmigration Policy and the National 1nterest 35-45 (Joint Comm. Print 1981) (discussing the impact of undocumented immigration on the labor market).

82. 688 F. Supp. 1, 3-4 \& n.2 (D.D.C. 1988).

83. See Fed'n for Am. Immigration Reform, Inc. v. Reno, 93 F.3d 897, 900 (D.C. Cir. 1996) (noting that plaintiff's theory of injury was that the "rush of immigrants [resulting from the Mariel boatlift] adversely affects the welfare of the Federation's members by generating unemployment and wage reduetions and by placing burdens on public services such as hospitals and schools, especially in the Miami area"). But cf. David Card, The Impact of the Mariel Boatlift on the Miami Labor Market, 43 Indus. \& LAB. Rel. REv. 245, 250 (1990) (finding that the 1980 Mariel boatlift did not affect the wages of non-Cuban Miami residents). 
constitutional standing to challenge the immigration policy. ${ }^{84}$ As with associational injuries, courts are clearly concerned with the potential breadth of the causal logic of these sorts of economic injuries. ${ }^{85}$ Still, it is undisputed that citizens can be economically injured in legally cognizable ways by immigration law.

\section{Expressive Injuries}

While courts have sporadically acknowledged that immigration law can inflict associational and economic injuries on citizens, they have not considered the possibility that immigration law might injure citizens much more broadly. The notion that immigration law could inflict broad-ranging injuries on citizens, rather than on the aliens who are the explicit subjects of immigration law, might seem surprising. But it should not. Immigration law plays a central role in national self-definition ${ }^{86}$ By regulating the admission, exclusion, and status of aliens, it pervasively regulates the boundaries of the national political community. ${ }^{87}$ Such regulation may injure citizens by expressing a constitutionally impermissible conception of political identity. And as constitutional law has suggested elsewhere, those expressive injuries may be legally cognizable-that is, sufficient to confer standing on citizens to challenge immigration policies. ${ }^{88}$

\section{Expressive Harms and Standing}

To understand this third potential basis for citizen standing to challenge immigration law, it is neccssary first to sketch out the relationship between expressive harms and standing to raise claims. ${ }^{89}$ Expressive harms differ from typical common law injuries in that expressive harms are not directly concerned with the material consequences of government actions. ${ }^{90}$

84. See N.W. Forest Workers Ass'n, 688 F. Supp. at 3 n.2 (holding that nonprofit organization "concerned with the economic, environmental and demographic effects of immigration" had standing to challenge immigration regulations on the ground that the regulations improperly expanded the scope of a guest worker program); cf. Fed'n for Am. Immigration Reform, Inc., 93 F.3d at 900 (assuming, without deciding, that a nonprofit immigration group's alleged economic injury stemming from Mariel boatlift sufficed for purposes of constitutional standing).

85. See Fed'n for Am. Immigration Reform, Inc., 93 F.3d at 901 (expressing concern that a citizen's interest in the nationwide economic effects of immigration policy is so widespread and common that it "seems particularly well-suited for redress in the political rather than the judicial sphere").

86. See infra text accompanying notes 104-09; see also infra Part 11.C.3.a.

87. See infra Part 11.C.3.a.

88. See infra Part 11.C.2.

89. I focus here only on standing to raise constitutional claims because I am principally concerned in this Article with the capacity of citizens to raise constitutional challenges to immigration laws.

90. See, e.g., Elizabeth S. Anderson \& Richard H. Pildes, Expressive Theories of Law: A General Restatement, 148 U. PA. L. Rev. 1503, 1531 (2000); Adam B. Cox, Expressivism in Federalism: A New Defense of the Anti-Commandeering Rule?, 33 Loy. L.A. L. Rev. 1309, 1317 (2000); Richard H. Pildes, Why Rights Are Not Trumps: Social Meanings, Expressive Harms, and Constitutionalism, $27 \mathrm{~J}$. 
Instead, they concern the social meaning of these actions. ${ }^{91}$ According to expressive theories of the law, government actions can be wrong-and unlawful--because they express impermissible meanings or valuations. ${ }^{92}$ While this account of the law might seem at first exceptional, it is not. As many scholars have demonstrated, law generally, and constitutional law in particular, is frequently concerned with the expressive dimension of action. ${ }^{93}$ Contemporary equal protection doctrine, Establishment Clause jurisprudence, and other areas of constitutional law either explicitly incorporate expressive concerns or are in part best explained by expressive theories. ${ }^{94}$

Although expressive concerns are an important part of constitutional law, the Supreme Court has not embraced expressivism in any systematic way. Consequently, the Court has not discussed the relationship between expressive harms and Article III standing. As explained earlier, the question whether an injury is legally cognizable is not, as standing law's core requirement of injury in fact might linguistically suggest, a question of fact ${ }^{95}$ Rather, the determination whether something constitutes a cognizable injury is inevitably based on legal conventions. ${ }^{96}$ Those legal conventions are not trans-substantive; they depend on the specific legal claims at stake. ${ }^{97}$ Accordingly, it is not possible to set out an account of the relationship between expressive harms and standing in constitutional cases that is independent of the substantive constitutional provisions at issue in those cases. ${ }^{98}$

These features of standing law make clear that we should expect the Court to treat potential expressive harms differently in different constitutional contexts. Certainly, the Court's treatment of potential expressive harms has varicd. In some contexts, such as in Establishment Clause and equal protection jurisprudence, the Supreme Court has on occasion

Legal Stud. 725, 726 (1998); Richard H. Pildes \& Richard G. Niemi, Expressive Harms, “Bizarre Districts," and Voting Rights: Evaluating Election-District Appearances After Shaw v. Reno, 92 MiCH. L. REv. 483, 506-07 (1993).

91. See, e.g., Anderson \& Pildes, supra note 90, at 1527-31; Cox, supra note 90, at 1317; Pildes \& Niemi, supra note 90 , at 506-07.

92. See Anderson \& Pildes, supra note 90, at 1527-31; Cox, supra note 90, at 1317; Pildes \& Niemi, supra note 90, at 506-07. But cf. Matthew D. Adler, Expressive Theories of Law: A Skeptical Overview, 148 U. PA. L. REv. 1363 (2000) (arguing that expressive theories of law are unpersuasive).

93. See, e.g., Anderson \& Pildes, supra note 90, at 1531-63.

94. See id. (surveying evidence of expressive concerns in various areas of constitutional law); Pildes \& Niemi, supra note 90, at 506-16 (arguing that the Shaw redistricting cases are best understood in expressive terms); Cox, supra note 90, 1329-40 (arguing that some contemporary federalism jurisprudence is best understood as turning on the Supreme Court's expressive concerns).

95. See supra notes $66-68$ and accompanying text.

96. See id.

97. See, e.g., Fletcher, supra note 63, at 229; Sunstein, Standing After Lujan, supra note 63, at 190-92.

98. For an attempt to lay out a relatively trans-substantive account, see Note, Expressive Harms and Standing, 112 HARV. L. REv. 1313 (1999). 
accepted an alleged expressive harm as sufficient to confer standing. ${ }^{99}$ In contrast, it has rejected the cognizability of alleged expressive harms in other contexts. ${ }^{100}$ Only some of this variation is explainable in terms of differences between the substantive constitutional provisions at stake. In remarkably similar Establishment Clause contexts, for example, the Court considered cognizable a potential expressive harm in one case but rejected a seemingly identical harm in another. ${ }^{101}$ Moreover, the Court has suggested on one occasion that expressive harms alone can never be sufficient to confer standing. ${ }^{102}$ Thus, the Court's treatment of the relationship between expressive harms and standing is at least partially incoherent-an unsurprising fact, given both the theoretical shortcomings of standing law generally and the Court's reluctance to acknowledge openly the role expressive harms play in constitutional law.

This Article does not attempt to reconcile the Court's meandering jurisprudence. Rather, I advance a more modest point: because the Supreme Court has considered some expressive injuries sufficient to confer standing, one must also consider the possibility that citizens should have standing to challenge an immigration law on the basis that the law inflicts a cognizable expressive injury on them. And as the discussion below explains, the Supreme Court has recently provided strong evidence that citizens can be subjected to such injuries by immigration law.

\section{Immigration Law and National Political Identity}

Constitutional voting rights law provides a powerful analogy for immigration law's potential to inflict cognizable expressive injuries on citizens. In the context of racial redistricting, the Supreme Court has concluded that members of a political community can be injured in a constitutionally cognizable way by government policies that constitute the boundaries of that political community on the basis of race. ${ }^{103}$ In other words, members of a political community can be injured by the laws that define their political community. Much like lcgislative redistricting, immigration law regulates political community boundaries. There is reason to think, therefore, that citizens, as insiders in the national political

99. See Shaw v. Reno, 509 U.S. 630 (1993) (racial gerrymandering claim arising under the Equal Protection Clause); Flast v. Cohen, 392 U.S. 83 (1968) (Establishment Clause claim); see also County of Allegheny v. ACLU, 492 U.S. 573 (1989) (same); Lynch v. Donnelly, 465 U.S. 668 (1984) (same).

100. See, e.g., Allen v. Wright, 468 U.S. 737, 755 (1984) (stating that the "stigmatizing injury often caused by racial discrimination" is itself insufficient to confer standing).

101. Compare Flast v. Cohen, 392 U.S. 83 (1968) (granting standing), with Valley Forge Christian Coll. v. Ams. United for Separation of Church \& State, Inc., 454 U.S. 464 (1982) (denying standing).

102. See Allen, 468 U.S. at 755 (holding that "the stigmatizing injury often caused by racial discrimination ... accords a basis for standing only to "those persons who are personally denied equal treatment' by the challenged discriminatory conduct"' (quoting Heckler v. Mathews, 465 U.S. 728, 739 $40(1984))$.

103. See infra text accompanying notes 111-19. 
community, can be cognizably injured by immigration policies that define that community. Race-based (and perhaps other) immigration policies, for example, may harm citizens by expressing a constitutionally impermissible conception of national political identity. Consequently, citizens should have standing to challenge immigration laws that regulate membership in the national community in ways that allegedly conflict with our constitutional traditions and inflict such expressive injuries.

The fact that immigration law controls the makeup of the national community is the basis for much of the immigration policy enacted in the United States. Since the 1880 s, immigration law has frequently been used to protect the interests of insiders by excluding those whose presence has been thought to corrupt the national community in some way. The Chinese Exclusion Acts, ${ }^{104}$ the national origins quota system, ${ }^{105}$ and the pre-1952 naturalization laws ${ }^{106}$ were all designed to protect and foster an ethnic national identity by keeping the American national community White. ${ }^{107}$ The federal government has historically used immigration rules to exclude persons on ideological grounds. ${ }^{108}$ Today, legal and political actors continue to argue that immigration law should be used to preserve some particular conception of our national identity. ${ }^{109}$ Moreover, there is increasing

104. Act of May 6, 1882, ch. 126, 22 Stat. 58, repealed by Act of Dec. 17, 1943, ch. 344, 57 Stat. 600 .

105. The national origins quota system restricted the number of visas available to natives of each country based on the number of Americans who could trace their ancestry to that country. See MARION T. Bennett, American Immigration Policies: A History 47-58 (1963); E.P. Hutchinson, Legislative History of American Immigration Policy, 1798-1965, at 468-74 (1981). The first permanent quota law was enacted as part of the Immigration Act of 1924. Act of May 26, 1924, ch. 190, 43 Stat. 153 (amended 1952); see also House Comm. ON THE Judiciary, I loth Cong., Grounds

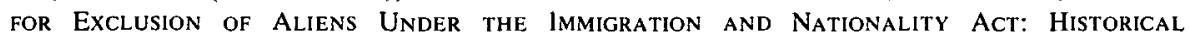
Background and Analysis 22-23 (Comm. Print 1988). The quota system was repealed in 1965. See Act of Oct. 3, 1965, Pub. L. No. 89-236, 79 Stat. 911.

106. See Gabriel J. Chin, The Civil Rights Revolution Comes to Immigration Law: A New Look at the Immigration and Nationality Act of 1965, 75 N.C. L. Rev. 273, $281-82$ (1996); infra text accompanying notes 133-37.

107. See Chin, supra note 106, at 279-82; Chin, supra note 3, at 7 (describing exclusion of most people of Asian ancestry from 1882 to 1965); see also The Chinese Exclusion Case, 130 U.S. 581, 595 (1889) (noting perceived "great danger that at no distant day [the West Coast] of our country would be overrun by [Chinese immigrants] unless prompt action was taken to restrict their immigration"); ALEINIKOFF, supra note 32, at 161 ("Membership decisions may display virulent intolerance based on race, political opinion, or lifestyle.").

108. See, e.g., Steven R. Shapiro, Ideological Exclusions: Closing the Border to Political Dissidents, 100 HARV. L. Rev. 930, 930-35 (1987).

109. Peter Brimelow, for example, has argued that we need rcstrictive immigration policies to protect America's core ethnic identity, a move that would seem to reintroduce the national origins quota system. See Peter Brimelow, Alien Nation: Common Sense About America's IMMigration Disaster (1995). Michael Walzer has also argued, though from a very different perspective, that immigration law should be used to regulate national identity. See MiCHAEL WALZER, Spheres of Justice: A Defense of Pluralism and Equality 50 n.* (1983) (discussing the fact that "political communities ... have a right to protect their members' shared sense of what they are about"); Joseph H. Carens, Aliens and Citizens: The Case for Open Borders, 49 Rev. PoL, 251, 266 (1987) 
evidence that race, religion, and ideology still play an important role in the formulation of immigration policy-including refugee and asylum policies, employment admissions policies, and many policies adopted by the federal government in the wake of September 11 th. ${ }^{110}$

Despite this pervasive understanding that immigration laws constitute the national political community, little attention has been paid to the possibility that this constitutive process might injure existing members of the national community. But just as immigration law's rules of admission and exclusion can reinforce the preferred identity of a political community, they can also express a harmful conception of national community membership.

The important question, then, is not whether such expressive injuries to citizens can exist, but whether such injuries should ever be considered legally cognizable. Constitutional voting rights case law contains strong evidence that some immigration policies-such as race-based policiescould inflict judicially cognizable expressive injuries on citizens by expressing a constitutionally impermissible conception of national political identity. In a recent series of racial redistricting cases beginning with Shaw v. Reno, ${ }^{11}$ the Supreme Court recognized a closely analogous injury. Shaw and its progeny concerned the constitutionality of certain majority-Black congressional districts drawn throughout the South following the i 990 census. ${ }^{112}$ In those cases, the Court held that redistricting schemes that paid too much attention to race impinged upon the equal protection rights of all

(noting that "Walzer's central claim is that exclusion is justified by the right of communities to selfdetermination"); $c f . i d$. at 251 (noting that most people see "[t]he power to admit or exclude aliens" as "essential for any political community").

110. See infra text accompanying notes 174-79.

111. 509 U.S. 630 (1993) (Shaw I).

112. Miller v. Johnson, 515 U.S. 900 (1995); United States v. Hays, 515 U.S. 737 (1995); Bush v. Vera, 517 U.S. 952 (1995); Shaw v. Hunt, 517 U.S. 899 (1996) (Shaw II); Hunt v. Cromartie, 526 U.S. 541 (1999); Easley v. Cromartie, 532 U.S. 234 (2001). The districts at issue in these cases were the products of state redistricting efforts under Section 5 of the Voting Rights Act (VRA). The VRA was enacted principally to ensure that states and local governments did not deny or abridge anyone's right to vote on account of race. See 42 U.S.C. $\$ 1973$ (2000). Seetion 5 of the Act prohibits certain jurisdictions from implementing changes to "any voting qualification or prerequisite to voting, or standard, practice, or procedure with respect to voting" without federal authorization. 42 U.S.C. $\S 1973 \mathrm{c}(2000)$. Legislative reapportionment plans are covered by this preclearance requirement. See, e.g., Beer v. United States, 425 U.S. 130, 133 (1976). The jurisdictions subject to the requirements of Section 5 may seek federal authorization in two ways. First, they can request a declaratory judgment in the United States District Court for the District of Columbia that the redistricting plan "does not have the purpose and will not have the effect of denying or abridging the right to vote on account of race or color." Id. Second, the jurisdictions can seek administrative preclearance from the attomey general. Id. In the late 1980s and early 1990s, the Justice Department initially refused to preclear the redistricting schemes of several Southern states. In response to the Justice Department's objections, these states drew up new reapportionment plans that added majority-Black districts. Some of these districts looked starkly gerrymandered. They were promptly challenged in a series of lawsuits. See, e.g., Shaw v. Reno, 509 U.S. 630 (1993) (Shaw I); United States v. Hays, 515 U.S. 737 (1995). 
members residing within the challenged district. ${ }^{113}$ Consequently, the Court granted standing to all members of a challenged district-White and Black - to challenge the district's constitutionality under the Equal Protection Clause. ${ }^{114}$

There has been a good deal of debate about the nature of the injury at stake in the Shaw cases. ${ }^{115}$ It is clear that the injury is not one of vote dilution or vote denial. ${ }^{116}$ Nor is the bare fact of racial classification the cognizable harm to the district members recognized by the Court. ${ }^{117}$ As Richard Pildes, Elizabeth Anderson, Richard Niemi, and others have explained, the most plausible understanding of the injury recognized in the Shaw cases is that it is an expressive one:

[T] he problem is that certain districts convey the message that political identity is, or should be, predominantly racial.... [The] effect is a matter of the conception of political identity... expressed through the law.... The very creation of these districts expresses, in the Court's view, a constitutionally

113. See Shaw I, 509 U.S. at 649; Miller, 515 U.S. at 915-20; Vera, 517 U.S. at 958-59; Shaw II, 517 U.S. at $904-07$; Hunt, 526 U.S. at 546-47; Easley, 532 U.S. at 237-38.

114. Hays, 515 U.S. at $742-47$ (denying standing to plaintiffs who did not live in the district that was the primary focus of their racial gerrymandering claim); Shaw II, 517 U.S. at 904 ("In [Hays] we recognized that a plaintiff who resides in a district which is the subject of a racial-gerrymander claim has standing to challenge the legislation which created that district, but that a plaintiff from outside that district lacks standing. ...") (citation omitted). Cf. Sinkfield v. Kelley, 531 U.S. 28, 30-31 (2000) (denying, on the reasoning in Hays, standing to White Alabama voters residing in districts adjacent to majority-minority districts--even though the voters styled their lawsuits as ehallenges to their own districts).

115. Compare, e.g., John Hart Ely, Standing to Challenge Pro-Minority Gerrymanders, 111 HARv. L. REv. 576 (1997), with Samuel Issacharoff \& Pamela S. Karlan, Standing and Misunderstanding in Voting Rights Law, 111 HARV. L. REV. 2276 (1998).

116. See Shaw I, 509 U.S. at 641 ("In their complaint, appellants did not claim that the General Assembly's reapportionment plan unconstitutionally 'diluted' white voting strength."); id. at 636 (noting that the plaintiffs did not allege that the plan violated the one person, one vote principle). Moreover, the Court's standing doctrine in the Shaw cases makes clear that the Court did not conceive of the injury as one of vote dilution. In the Shaw cases, the Court extended standing to all voters within the challenged district. See Hays, 515 U.S. at 742-47; Shaw II, 517 U.S. at 546-47. This standing rule is not consistent with a vote dilution injury. Standing to challenge vote dilution, after all, would only have extended to White voters challenging the majority-Black district, not to all voters. See Issacharoff \& Karlan, supra note 115 , at $2280-85$ (explaining that the injury rccognized by the Court in Shaw could not be an injury of vote dilution or denial).

117. The standing limitation in the Shaw cases demonstrates that the Court did not conceptualize the injury as one stemming from the simple fact of racial classification. When the issue of standing arose in those cases, the Court denied standing to plaintiffs who lived outside the challenged districts. See, e.g., Hays, 515 U.S. at 742-47. But these voters had also been subject to a racial classification. The mechanics of redistricting require this: in order to determine whom to include and whom to exclude, a state must classify voters who end up excluded, as well as those in the challenged distriet. Thus, the Court's decisions in the Show cases are not consistent with the assertion that the injury at issue was one of bare racial classification. See lssacharoff \& Karlan, supra note 115, at 2288. 
impermissible conception of the role of race in the design of democratic institutions. ${ }^{118}$

In other words, by paying inappropriate attention to race, the redistricting process expressed a constitutionally impermissible notion of what membership in the political community meant. And although Shaw I did not explicitly use the language of expressive harms, the Court has subsequently suggested that the injury Shaw I recognized is indeed an expressive one. ${ }^{119}$

Because the Court lacks a coherent theory of the role of expressive harms in constitutional law, it did not adequately explain in the Shaw cases why the expressive harm was judicially cognizable, nor did it adequately explain why the injury extended to all voters in the challenged congressional district but no one outside. If the description of the injury set forth above is accurate, however, the nature of the injury helps to explain why the injury extended to all members of the challenged district. Because the injury concerned the constitution of political identity, it is understandable that the members themselves-and not those excluded from the community-were considered injured. After all, it was their political identity that the gerrymandered district implicated.

This does not mean that the specific standing limitation established in the Shaw line of cases is necessarily correct. By limiting standing to district members, the Court suggested that the political community affected by the excessive use of race was one constituted by thc challenged congressional district. This conclusion is far from clear. The districts challenged in the Shaw cases were the products of state-wide redistricting processes. ${ }^{120}$ These districts were also congressional districts-subunits of the national political community. Thus, the Court may have becn mistaken to cabin its conception of the relevant community so narrowly. ${ }^{121}$

118. Anderson \& Pildes, supra note 90, at 1539; accord Deborah Hellman, The Expressive Dimension of Equal Protection, 85 MiNN. L. REv. 1, 26 (2000) (reading the Shaw doctrine as concerned with "expressive content of the state action"); Pildes \& Niemi, supra note 90, at 506 ("One can only understand Shaw, we believe, in terms of a view that what we call expressive harms are constitutionally cognizable."); Richard H. Pildes, Principled Limitations on Racial and Partisan Redistricting, 106 Y ALE L.J. 2505, 2539 (1997) ("As the Court now forthrightly says, Shaw addresses expressive harms. Shaw is therefore concerned with the social perceptions and understandings conveyed by extreme districting practices.").

119. See Bush v. Vera, 517 U.S. 952, 984 (1996) (plurality opinion) ("[Wle also know that the nature of the expressive harms with which we are dealing ... are such that bright-line rules are not available."); id. at 1053 (Souter, J., dissenting) ("Th[e] injury [in the Shaw cases] is probably best understood as an 'expressive harm,' that is, one that 'results from the idea or attitudes expressed through a governmental action, rather than from the more tangible or material consequences the action brings about." (quoting Pildes \& Niemi, supra note 90 , at 506-07)).

120. See Vera, 517 U.S. at 956-57 (Texas); Miller v. Johnson, 515 U.S. 900, 907-08 (1995) (Georgia); Hays, 515 U.S. at 740-41 (Louisiana); Shaw I, 509 U.S. at 634-36 (North Carolina).

121. See Pildes \& Niemi, supra note 90, at 514 (suggesting that standing in the Shaw cases should extend to "perhaps any voter in North Carolina"); Pildes, supra note 118, at 2539 n.122 ("[A] more apt standing principle would grant standing to any resident of the state, or perhaps to anyone at all"). Note that Shaw I itself contains hints about why the Court might have focused in its standing analysis only 
Nevertheless, the principal insight of the Shaw cases remains: government regulation of the boundaries of a political community in an overly racialized way can inflict an expressive injury on the insiders-the existing members of the political community-that is cognizable under the Equal Protection Clause. ${ }^{122}$ Like redistricting laws, immigration law concerns the regulation of political community boundaries - in the case of immigration law, the boundaries of the national political community. This suggests that immigration laws could regulate the boundaries of the national political community in a fashion that expresses a constitutionally impermissible national political identity. Citizens should have standing to challenge immigration law in such instances. ${ }^{123}$

I do not mean to suggest that the Shaw cases entail the conclusion that all race-based immigration policies inflict cognizable expressive injuries on citizens. As many commentators have noted, evaluating the social meaning of government regulation is a highly context-specific process. ${ }^{124}$ Sorting

on the voters residing within the challenged distriet. In Shaw I, Justice O'Connor hints that specific representational harms may result from the cxpressive significance of the challenged district. See Shaw I, 509 U.S. at 648 (suggesting that the bizarre shape of the district might signal to elected officials that they represent a particular racial group "rather than their constituency as a whole"). In later eases, the Court made clear that the expressive harm did not depend on the existence of these representational harms; rather, the harm flowed directly from the meaning of the district. See Anderson \& Pildes, supra note 90 , at 1539. Nonetheless, this initial focus on the representational interests of the members of the challenged district appears to have bled into the Court's later standing analysis. See Hays, 515 U.S. at 745 .

122. It is important to note that citizen standing is not limited to those instances in which plaintiffs actually prove the existence of such an expressive harm. To satisfy the preliminary jurisdictional requirement imposed by Article III's standing rules, a plaintiff must only allege a legally cognizable injury. See, e.g., Allen v. Wright, 468 U.S. 737, 75 I (1984); Warth v. Seldin, 422 U.S. 490, 50 I (I975); cf. Duke Power Co. v. Carolina Envtl. Study Group, Inc., 438 U.S. 59, 70-71 (1978) (holding, with respect to the closely related question whether a plaintiff has asserted a cause of action, that the court has jurisdiction over the action so long as the cause of action alleged is not "patently without merit"). See generally Fletcher, supra note 63.

The Shaw cases operate in just this way. Even though the expressive injury at stake in the mcrits of those constitutional challenges appears to be the same injury relevant for standing purposes, the Supreme Court has upheld the standing of Shaw plaintiffs cven when it concluded that their claims failed on the merits. In Easley v. Cromartie, 532 U.S. 234 (2001), which concerned the North Carolina redistricting scheme adopted after remand in Shaw v. Hunt, 517 U.S. 899 (I996) (Shaw II), the Court for the first time rejeeted on the merits a Shaw challenge to a redistricting seheme. See 532 U.S. at 237. While it ruled against the plaintiffs on the merits, however, the Court did not dismiss the plaintiffs' appeal for lack of standing. Id. The Court's conclusion is eonsistent with its treatment of vote dilution claims; in vote-dilution cases, the Court similarly does not require plaintiffs to prove the existence of dilution to establish standing. See, e.g., Baker v. Carr, 369 U.S. 186, 208 (1962). Moreover, even were courts to treat as a standing question-rather than as a component of the merits determination-the question of whether a citizen had actually demonstrated the existence of an expressive injury stemming from immigration policy, this formal distinction would not alter the underlying analysis.

123. To be more aceurate, standing would extend to members of the national political eommunity. As the following discussion explains, permanent resident aliens (and perhaps others as well) are in many ways meaningful members of the national political community. See infra Part II.C.3.a. Thus, standing might extend to these community mombers as well.

124. See, e.g., Pildes \& Niemi, supra note 90, at 516-24; Cox, supra note 90, at 1340-47. 
out the expressive significance of various immigration laws would require complicated judgments about the social meaning of those regulations. ${ }^{125}$ This Article does not undertake that large project. Rather, this Article highlights the real possibility that immigration laws can inflict expressive injuries on citizens qua citizens, and that it is wrong to think that existing members of the national community cannot be constitutionally injured by government policies that regulate admission to that community. ${ }^{126}$

\section{Potential Objections}

\section{a. Political Community Regulation}

One might object to this citizen-standing argument on the ground that most immigration laws have very little to do with regulating the boundaries of the national political community. Perhaps naturalization laws regulate membership in that community, but not immigration law more generally: those laws, one might argue, simply regulate who can enter the physical territory of the United States, and on what terms. And if immigration law has little to do with regulating the political community, it would seem much less likely that immigration law could express constitutionally impermissible conceptions of national political identity. As the following discussion explains, however, the claim that immigration law has little to do with regulating the boundaries of the national political community is wrong. It is inconsistent with both the history of immigration regulation and the contemporary structure of immigration law.

First, the argument that immigration law generally concerns only the entrance and exit of newcomers belies the history of American immigration law. As discussed above, the United States has often used immigration law to preserve and promote certain (often unfortunate) notions of who we are as Amerieans. ${ }^{127}$

125. It should be noted, however, that there are reasons that it may be more plausible to conclude that racialized immigration policies inflict expressive harms cognizable under the Constitution's equal protection guarantee than it is to conclude that race-conscious redistricting docs so. One difficulty with the expressive harm the Shaw cases appear to recognize is that it may be grounded in a conception of the equal protection guarantee that links equality with colorblindness. But in the case of racially exclusionary immigration policies, the potential expressive injury seems more clearly connected to anti-subordination principles, which arguably have a better pedigree in equal protection jurisprudence.

126. I should point out that a Shaw-like expressive injury is not the only kind of expressive injury that immigration law could inflict on citizens. Other injuries are certainly possiblc. An ethnically or religiously restrictive immigration policy, for example, might also stigmatize the citizens whose ethnicities are disfavorcd by immigration law. See Motomura, Whose Immigration Law, supra note 3, at 1572 .

127. See, e.g., id. at 1582 . To say that immigration law regulates the boundaries of a political community is not to suggest that it is unconcerned with the promotion or protection of social, economic, or other types of community. Historically, American immigration law has been explicitly concerned with protecting ethnic and cultural communities. See, e.g., Stephen JAY Gould, The MISMEASURE OF MAN 260-62 (2d ed. 1996) (discussing the history of intelligence testing in immigration policy and its connection to theories of racial inferiority); see also infra notes 133-37 and 
Moreover, the contemporary structure of immigration regulation and constitutional law suggests that immigration law operates pervasively to regulate membership in the national political community, not just entrance to the physical territory controlled by the United States. ${ }^{128}$ In saying this, I do not mean to endorse any particular notion of what constitutes a political community or how exactly one comes to belong to such a community. Who is, or should be, a member of a political community is a subject of wide debate in legal and political philosophy scholarship. ${ }^{129}$ Regardless of how one defines membership, however, it is clear that immigration decisions are, at least in part, membership decisions.

One way to belong to a political community is to possess the legal status of citizenship. ${ }^{130}$ Even if acquiring citizenship is the only way to become a member of the national political community, many immigration laws meaningfully regulate membership. For those unfamiliar with the structure of contemporary immigration regulation, this conclusion may seem a stretch. Intuitively, the connection between immigration law and the national political community might seem demonstrable only with respect to one subset of immigration law: naturalization law. On a unitary "citizenship" model of the political community, all citizens are in the community, and all others are out. ${ }^{131}$ Because naturalization rules determine when an alien passes the final threshold of eligibility for citizenship, as well as the procedures according to which eligible aliens can formally acquire the status of citizenship, those rules may seem most clearly to regulate the boundaries of the national political community. ${ }^{132}$

But even if one conceptualizes the boundaries of the national political community in this formal legal fashion, naturalization law is far from the most important gatekeeper of membership. Today, other immigration rules

accompanying tcxt. And immigration restrictions are sometimes still dcfended in those terms today. See, e.g., BRIMELOW, supra note 109. In the service of efforts to regulate ethnic, cultural, or other forms of community, however, immigration laws use the boundaries of the national political and geographic community.

128. I use the terms "regulate" and "constitute" interchangeably throughout this discussion because this section is not concemed with the question of how a national political community was constituted in the past. Instead, it is concerned with the ongoing decisions that a political community makes about its present and future makeup.

129. Unsurprisingly, there is little consensus concerning the precise nature and scope of political communities generally or America's national political community in particular. Obviously, the degree of consensus depends on the level of abstraction of the description. Many, perhaps most, contemporary theorists agree that political communities are "groups that possess (or aspire to) extensive selfgovernment." See Joseph H. Carens, Culture, Citizenship, and Community: A Contextual. EXPLORATION OF JUSTICE AS EVENHANDEDNESS 167 (2000). There is sharp disagreement about many other questions conceming the nature and makeup of political communities, however, including what persons are or should be included within a particular community.

130. See id. at 161 ("In this idealized conception [of citizenship], the nation-state is the only locus of political community that really matters and citizenship just means membership in a nation-state.").

131. Id.

132. See 8 U.S.C. $\$ \$ 1421-1458(2000)$. 
play a significant role in determining eligibility for citizenship and thus also regulate entrance into the political community in a meaningful sense. Historically, this was less the case. During the nineteenth and early twentieth centuries, the United States consistently employed very restrictive naturalization rules-or, to be more specific, race-based naturalization and citizenship policies. ${ }^{133}$ The first naturalization statute, passed in the United States' infancy, permitted only "white" persons to naturalize. ${ }^{134}$ The Fourteenth Amendment extended citizenship after the Civil War to all persons born in the United States, ${ }^{135}$ but race-based naturalization policies continued. ${ }^{136}$ Congress did not extend the right to naturalize to persons of every Asian nationality until $1952 .{ }^{137}$ Today, however, naturalization law looks very different. The rules governing who can naturalize are themselves race-neutral and relatively lenient. To naturalize, a lawful permanent resident need only be over the age of eighteen, reside in the United States for five years, ${ }^{138}$ and satisfy a few other straightforward requirements. ${ }^{139}$

By relaxing naturalization rules, Congress has made the rules governing permanent and long-term residence in the United States the more important gatekeepers of citizenship. ${ }^{140}$ (In other words, the rules regulating eligibility for permanent and long-term residency have in some ways themselves become important naturalization regulations.) Gaining admission for long-term residency to the United States is incredibly difficult. Quotas stringently limit the diversity visa lottery, ${ }^{141}$ work visas that provide a path

133. See T. Alexander Aleinikoff \& Rubén Rumbaut, Terms of Belonging: Are Models of Membership Self-Fulfilling Prophecies?, 13 GEO. IMM1GR. L.J. 1, 4 (1998).

134. See Aet of Mar. 26, 1790, ch. 3, 1 Stat. 103 (retaining restriction of naturalization to "free white person[s]"), repealed by Act of Jan. 29, 1795, ch. 20, 1 Stat. 414.

135. U.S. CoNST, amend. XIV, $\S 1$ ("All persons born or naturalized in the United States and subject to the jurisdiction thereof, are citizens of the United States and of the state wherein they reside.").

136. Persons of African descent were added to the naturalization act in 1870. See Act of July 14, 1870 , ch. $254, \S 7,16$ Stat. 254,256 . But all "races indigenous to the Western Hemisphere" were not added to the naturalization act until 1940. See Nationality Act of 1940 , ch. 876, § 303, 54 Stat. 1137 , 1140 .

137. See 1mmigration and Nationality Act of 1952, ch. 477, $\S 311,66$ Stat. 163, 239 (codified at 8 U.S.C. $\S 1422(2000)$ ) ("The right of a person to become a naturalized citizen of the United States shall not be denied or abridged because of race or sex or because such person is married.").

138. 8 U.S.C. $\$ 1427(a)(1)(2000)$.

139. See 8 U.S.C. $\S \S 1421-1458$ (2000). For most immigrants, these additional requirements include demonstrating a basic understanding of American history and government, 8 U.S.C. $\S 1423(\mathrm{a})(2)$, satisfying a good moral standing requirement, $\S 1427(\mathrm{a})(3)$, and taking an oath of allegiance, $\S 1448$.

140. See Aleinikoff, supra note 66 , at 15 ("From the perspective of citizenship-as-membership, immigration decisions are membership decisions, and the immigration system is a process for seleeting and evaluating candidates for membership."); David A. Martin, Due Process and Membership in the National Community: Political Asylum and Beyond, 44 U. PITT. L. Rev. 165, 201 (1983) ("No cumbersome screening criteria or numerical quotas apply [at the naturalization stage]. The only significant qualitative and quantitative restrictions apply at the earlier stage, when decisions are made on whether to grant immigrant visas or otherwise to allow admission for permanent residence.").

141. See 8 U.S.C. $\$ 1153($ e) (2000). 
to permanent residency are difficult to obtain, and detailed grounds of exclusion rule out admission for much of the world's population. ${ }^{142}$ In contrast, naturalizing after becoming a permanent resident is fairly easy. That many immigration rules do more to regulate citizenship eligibility than do naturalization rules shows that broad swaths of immigration law, though not formally considered naturalization rules, regulate membership in the national political community by controlling eligibility for citizenship. ${ }^{143}$

America's lax naturalization rules and stringent laws governing permanent residency and the like suggest a second, more direct explanation of how immigration law regulates membership in the national political community. The structure of immigration regulation shows that resident noncitizens, and perhaps other aliens, are considered to be meaningful members of the national political community in legal, social, and other senses. ${ }^{144}$ In other words, the unitary model of membership in the national political community, in which the legal status of citizenship is the sole determinant of the nation-state, is a poor fit for the reality of contemporary immigration regulation in the United States. ${ }^{145}$ For this reason as well, much of immigration law-not just naturalization law-concerns national community regulation. ${ }^{146}$

One might object to the possibility of alien membership by arguing that, as a matter of political philosophy, political communities must entail an identity between those who exercise the power of self-government and those who are subject to that government. ${ }^{147}$ On this social contract

142. See 8 U.S.C. $§ 1182(2000)$.

143. That many people who are eligible to naturalize choose not to does not undermine this conclusion. Naturalization rules merely establish who is eligible for citizensbip. These rules do not decide who will beeome a citizen. They regulate entrance to the politieal community by denying entrance to some, but they do not require entrance by anyone. Thus, the fact that many permanent residents choose not to become citizens is irrelevant. The permanent residency rules still play a large (probably the central) role in determining who is eligible for citizenship.

144. To say this is not to argue that certain persons should, as a matter of political theory or morality, be admitted to membership in the political community. For an example of sueh an argument, see WALzER, supra note 109. Nor am 1 making a (related) claim about whether a territorially defined political community such as a nation-state has a moral right to regulate admission in order to preserve a certain vision of the community. For an argument that, as a matter of contemporary political theory, borders must be generally open to migration, see Carens, supra note 109 .

145. See CARENS, supra note 129 , at 162 ("One way to belong to a politieal community is to possess the legal status of a citizen.... [But] this model [of the nation-state] fails to capture contemporary realities or to provide good reasons for changing current practices to eonform to the unitary ideal.").

146. See Martin, supra note 140, at 201 ("[W]hen aliens at the threshold seek an indefinite stay here, they are asking significantly to become members of our politieal community-not at the innermost level of membership represented by citizenship, but for an important level of membership nonetheless. Membership, in short, is a matter of degree."); cf. WALZER, supra note 109, at 63 ("Admission and exclusion... suggest the deepest meaning of self-determination."); ALEINIKOFF, supra note 32, at 177; CARENS, supra note 129, at 213.

147. Michael Walzer grounds his work in this conception of political community, but reasons from this conception that eitizenship must be extended to all residents within a nation-state. See Michael 
account, one might contend, membership cannot be extended beyond those who hold the legal status of citizenship, and it is those who possess that status who both hold the political power and are subject to it. But this conception of political communities does not accurately represent the national political community in the United States. In the United States, citizens are not the only persons subject to the coercive force of the state: every person within the country's geographic jurisdiction is subject to the laws of the United States, regardless of whether that person is a citizen. ${ }^{148}$ Moreover, the category of citizenship does not accurately describe those who exercise the power of self-government in this country. Many citizens cannot participate in the political process in various ways. ${ }^{149}$ Conversely, many noncitizens can participate, by lobbying, contributing to political candidates, or working on political campaigns. ${ }^{150}$

This does not mean that all those subject to the coercive force of the political community should be considered members of the political community, or that all those who can participate in some way in the political

Walzer, The Distribution of Membership, in Boundaries: National Autonomy and Its Limits 1, 31 (Peter G. Brown \& Henry Shue eds., 1981) ("The processes of self-determination through which a territorial state shapes its internal life must be open, and equally open, to all those men and women who live in the territory, work in the local economy, and are subject to local law.'); WALzER, supra note 109 , at 62 ; $c f$. Thomas Hobres, Leviathan 142-43 (Herbert W. Schneider ed., Liberal Arts Press 1958) (1651) (arguing that the success of a geographically defined political community depends on every member's consenting unconditionally to a single authority); NEUMAN, supra note 3, at 9 (surveying social contract theories of government, which were "motivated by the view that an individual obligation to obey must be grounded in individual consent"); Schuck, supra note 15, at 6-7 (suggesting that restrictive American immigration laws reflect the political philosophy of individual autonomy, in which obligation is based principally on consent).

148. In fact, many people beyond the physical boundaries of the United States are subject to its laws. Much criminal law is extraterritorial. See, e.g., United States v. Verdugo-Urquidez, 494 U.S. 259, 280-81 (1990) (Brennan, J., dissenting) (explaining that the federal government has successfully held foreign nationals criminally liable under a host of federal criminal statutes for conduct committed entirely outside the United States).

149. Felons, ex-felons, and children, for example, are generally not permitted to vote. See Developments in the Law-The Law of Prisons, 115 HARv. L. REv. 1838, 1942-49 (2002) (surveying state felon disenfranchisement laws). Ex-felons are also often prohibited from holding public office. See, e.g., FLA. ConST. art. VI, § 4; Mo. REv. STAT. § 561.021 (1995). More generally, many of the rules governing eligibility to vote in national elections are determined by the states. See U.S. Const. art. $1, \S \S 2-3$, amended by U.S. CoNST. amend. XVII, $\S 1$; art. 11, $\$ 1$. But we do not conventionally think that states thereby regulate membership in the national political community. To the contrary, states are generally prohibited as a matter of constitutional law from regulating entrance to that community.

150. See 2 U.S.C. $\$ 441$ e (2000); Bruce D. Brown, Alien Donors: The Participation of NonCitizens in the U.S. Campaign Finance System, 15 YALE L. \& PoL'Y REv. 503, 503-04 (I997) (explaining that permanent resident aliens are permitted under campaign finance laws to fund U.S. political campaigns and noting that this provides these aliens "a significant entrée into the American political community"). Also, aliens have at various times during our country's history been permitted to vote in state and national elections. NEUMAN, supra note 3, at 63-70; Jamin B. Raskin, Legal Aliens, Local Citizens: The Historical, Constitutional and Theoretical Meanings of Alien Suffrage, 141 U. PA. L. Rev. 1391, 1397-1417 (1993); Gerald M. Rosberg, Aliens and Equal Protection: Why Not the Right to Vote?, 75 Mich. L. REv. 1092, $1095-99$ (1977). 
process should be. Nonetheless, the complex relationships between political participation, citizenship, and membership in the political community do suggest that, whether viewed from the perspective of legal practice or social reality, it is inaccurate to understand membership in the national political community as defined solely by the legal status of citizenship. Instead, membership may take different forms or degrees, with citizenship at the center but others also included within the ambit of the political community. ${ }^{151}$ The daily lives of long-term residents in the United States comport with this conclusion and further confirm that resident aliens are members of the national political community. Their everyday existence is nearly indistinguishable from that of citizens. They work, pay taxes, and raise families in the same way that citizens do. And their obligations to the community are far greater than the fiscal ones imposed by tax obligations: resident aliens are, for example, subject to the draft. ${ }^{152}$

Constitutional law likewise often treats resident aliens (and sometimes even other aliens) as meaningful members of the national political community. ${ }^{153}$ Throughout much of its jurisprudence relating to aliens, the Court has suggested that the boundaries of the national political

151. Various commentators have made this point. As David A. Martin has argued:

[O]ur notions of membership in the national community are more complex and multi-layered than can be captured in the concept of citizenship alone. The innermost members may be the only ones entitled to vote and hold office. But permanent resident aliens, members in the next wider circle of concentric communities that make up the nation ... are entitled by virtue of that membership alone to enter fully into virtually all other aspects of community life.

Martin, supra note 140, at 201-02. Similarly, Joseph $\mathrm{H}$. Carens has argued that there are at least three different dimensions of citizenship-the legal, the psychological, and the political. The legal dimension of citizenship refers to the formal rights and duties that one possesses as a member of a political community; the psychological dimension to one's sense of identification with the political community or communities to which one belongs; the political dimension to one's sense of the representational legitimacy of those who act authoritatively on behalf of and in the name of the political community.... An adequate conception of citizenship will have to leave room for these various forms of multiplicity, and ... it will have to differ markedly from the conventional unitary understanding if it is to provide a satisfactory empirical and normative account of citizenship in the modern world.

Carens, supra note 109, at 162; see also Elsa M. Chaney, Migrant Workers and National Boundaries: The Basis for Rights and Protections, in Boundaries: National. Autonomy and ITS Limits, supra note 147, at 39 (arguing that "there might be intermediate stages between the condition of Walzer's stranger in Fredonia and that of the citizen," but not making clear whether she means that the concept of political community membership is multilayered or rather that those who are not members must nonetheless be afforded some protections when they reside within the geographic territory of the political community).

152. 50 U.S.C. app. § 453(a) (2000); see also Graham v. Richardson, 403 U.S. 365, 376 (1971); Charles E. Roh, Jr. \& Frank K. Upham, The Status of Aliens Under United States Draft Laws, 13 HaRv. INT'L L.J. 501, 502-14 (1972).

153. The Constitution also suggests that residence is an important aspect of political membership. U.S. ConsT. art. $1, \S 2$, cl. 2 (requiring a congressional representative to "be an inhabitant of that state in which he shall be chosen"); $i d$. art. $1, \S 3, \mathrm{cl} .3$ ("No Person shall be a Senator who... shall not, when elected, be an Inhabitant of that State for which he shall be chosen."); id. art. I, § 2, cl. 3 (not excluding aliens from the persons counted to determine the apportionment of representatives); see also NEUMAN, supra note 3 , at $142-43,147$. 
community are not determined only by citizenship or solely by reference to active participation (or eligibility to participate) in the day-to-day governing of the polity. Instead, the Court has indicated that there are degrees of belonging to the national community and that membership is more layered than binary. ${ }^{154}$ It is true that the connections of noncitizens to the United States that the Court frequently discusses are in part social, familial, economic, and cultural. But the Court has linked these connections with its understanding of membership in the political community, and it is in part because the Court considers these connections relevant to political membership that they confer ever-increasing legal rights on aliens who reside in the United States. ${ }^{155}$

All of this demonstrates that immigration law generally, not just naturalization law, is concerned with the regulation of the American political community. Like the congressional redistricting schemes at issue in the Shaw litigation, therefore, immigration law has the power to express beneficial or harmful conceptions of national political identity.

\section{b. The Limited Role of the Judiciary}

One might also object to the notion that an injury to all political community insiders could be judicially cognizable on the ground that courts are not the appropriate institution to remedy such injuries. ${ }^{156}$ In Shaw and its progeny, the Court clearly concluded that the injury to political community members was one appropriately addressed by the judiciary. Nonetheless, the political community at stake in the immigration context is larger than the one to which the Court extended standing in the Shaw cases. Because the potential injury is so widespread, or because it is inflicted on the polity in an undifferentiated way, one might argue that the injury should be remedied through the political process, rather than by the courts. While this

154. See United States v. Verdugo-Urquidez, 494 U.S. 259, 265 (1990); Landon v. Plasencia, 459 U.S. 21, 32 (1982); Graham, 403 U.S. at 376; Johnson v. Eisentrager, 339 U.S. 763, 770 (1950).

155. See, e.g., cases cited supra note 154. In some cases, the Supreme Court has suggested that membership in the national community may extend well beyond the bounds of lawful resident aliens. Consider Plyler v. Doe, 457 U.S. 202 (1982), which concerned a Texas law that authorized local school districts to bar undocumented children from attending public schools. In the course of invalidating the state law, the Court emphasized that the presence of the undocumented children within the country was an accomplished fact, and suggested that it would be improper to "deny[] these children a basic education" because doing so would "deny them the ability to live within the structure of our civic institutions ... and foreclose any realistic possibility that they will contribute in even the smallest way to the progress of our Nation." Id. at 218-23 (quoting Abington Sch. Dist. v. Schempp, 374 U.S. 203, 230 (I963) (Brennan, J., concurring)). As many immigration scholars have noted, this reasoning suggests that Plyler "may mark a fundamental break with classical immigration law's concept of national community." Schuck, supra note I5, at 54; accord Aleinikoff, supra note 66, at 25; Motomura, Phantom Constitutional Norms, supra note 3, at $584 \mathrm{n} .199$ (citing other scholars); cf. VerdugoUrquidez, 494 U.S. at 273.

156. Note that this objection, like the last, does nothing to undermine citizen standing on the basis of most of the associational and economic harms described above. See supra Parts 1I.A-B. It relates principally to the potential expressive injuries described above. 
argument is not implausible, it is wrong as a matter of constitutional law. The widespread and undifferentiated nature of immigration law injuries creates no obstacle to Article IIl standing. And constitutional requirements aside, there are good reasons to reject the contention that these injuries should be left to the political process.

The Supreme Court has refused to accord standing to plaintiffs complaining about "generalized grievances." 157 This limitation, sometimes styled prudential and sometimes constitutional, has been invoked by the Court to suggest that "wherc large numbers of Americans suffer alike, the political process, rather than the judicial process, may provide the more appropriate rcmedy for a widely shared grievance."158

Recently, however, the Court has made clear that the fact that an injury is widely shared is not a barrier to Article III standing. In FEC $v$. Akins, the Court clarified the generalized grievance cases by reading them in connection with standing law's requirement that an injury be concrete. ${ }^{159}$ The Court concluded that, while the abstractness and breadth of an injury may be correlated, the sheer breadth of an injury is not itself relevant. ${ }^{160}$ The Article III question turns only on whether the injury is sufficiently concrete. On this point, the Shaw cases concluded that the potential injury at stake in those cases is concrete enough to be judicially cognizable. Accordingly, there is no Article III obstacle to standing for the types of immigration law injuries described above.

While Akins makes clear that the widespread nature of an injury itself presents no Article III barrier to standing, there remains the question whether courts should decline to entertain suits involving widespread harms on prudential grounds. Prudential concerns were not at issue in

157. See Schlesinger v. Reservists Comm. to Stop the War, 418 U.S. 208, 217 (1974); see also Lujan v. Defenders of Wildlife, 504 U.S. 555, 575 (1992); Allen v. Wright, 468 U.S. 737, 751 (1984); United States v. Richardson, 418 U.S. 166, 173-77 (1974).

158. FEC v. Akins, 524 U.S. 11, 23 (1998).

159. Id. at 23-25. Akins is consistent with earlier cases in which the Court suggested that the widespread or uniform nature of an injury did not preclude standing. See Pub. Citizen v. U.S. Dep't of Justice, 491 U.S. 440, 449-50 (1989) ("The fact that other citizens ...might make the same complaint ... does not lessen appellants' asserted injury.”); United States v. Students Challenging Regulatory Agency Procedures (SCRAP), 412 U.S. 669, 687-88 (1973) ("[S]tanding is not to be denied simply because many people suffer the same injury ... . [Otherwise] the most injurious and widespread Government actions could be questioned by nobody."); see also Johnson v. De Grandy, 512 U.S. 997 , 1029-30 (1994) (Kennedy, J., concurring in part and concurring in the judgment) ("Furthermore, "[i]t is axiomatic that racial classifications do not become legitimate on the assumption that all persons suffer them in equal degree."' (quoting Powers v. Ohio, 499 U.S. 400, 410 (1991) (alteration in original)); Shaw v. Reno, 509 U.S. 630, 651 (1993) ("[R]acial classifications receive close scrutiny even when they may be said to burden or benefit the races equally."); Flast v. Cohen, 392 U.S. 83, 106 (1968) (extending standing to all federal taxpayers in a case concerning whether a federal spending program violated the Establishment Clause).

160. Akins, 524 U.S. at 24. Note also that the Supreme Court on at least one other occasion appears to have granted broad, nationwide standing on the basis of an expressive constitutional injury. See Flast v. Cohen, 392 U.S. 83 (1968). 
Akins, because Congress had decided that the nationwide informational injury at stake in that case should be legally cognizable. ${ }^{161}$ One could read Akins, however, as indicating that courts should be reluctant to grant standing for widely shared injuries without an indication from Congress that they should do so. ${ }^{162}$

The view that courts should decline to entertain claims involving widely shared injuries was influentially defended by then-Judge Scalia more than a decade before the Court's Akins decision. ${ }^{163}$ His central claim was that

[u]nless [a] plaintiff can show some respect in which he is harmed more than the rest of us... he has not established any basis for concern that the majority is suppressing or ignoring the rights of a minority that wants protection, and thus has not established the prerequisite for judicial intervention. ${ }^{164}$

Under this reasoning, widespread, unindividuated injuries should never be judicially cognizable, no matter how concrete they are. ${ }^{165}$ Scalia grounded this claim on the theory that courts are well suited to protecting minorities, who cannot protect themselves through the democratic process, but are ill suited to protect majorities, who dominate the democratic process. ${ }^{166}$

The argument that federal courts should refuse to adjudicate cases that involve unindividuated injuries to majoritarian interests, nowhere suggested by the text or history of Article $\mathrm{III}^{167}$ has some dramatic

161. Akins, 524 U.S. at 19-20.

162. Id. at 24 (stating that the fact that a "political forum may be more readily available when an injury is widely shared [would] counsel against ... interpreting a statute as conferring standing").

163. Antonin Scalia, The Doctrine of Standing as an Essential Element of the Separation of Powers, 17 Suffolk U. L. REv. 881 (1983). Unsurprisingly, Justice Scalia dissented in Akins. Akins, 524 U.S. at 29 (Scalia, J., dissenting).

164. Scalia, supra note 163 , at $894-95$.

165. Id. at 895 .

166. Scalia argued:

[T] he law of standing roughly restricts courts to their traditional undemocratic role of protecting individuals and minorities against impositions of the majority, and excludes them from the even more undemocratic role of prescribing how the other two branches should function in order to serve the interest of the majority itself. . .

... Where the courts [do enforce a majoritarian interest] they are likely (despite the best of intentions) to be enforcing the political prejudices of their own class.

Id. at 894, 896. But cf. Sunstein, Standing After Lujan, supra note 63, at 215-20 (criticizing Scalia's theory). There are, of course, close connections between Justice Scalia's conception of standing and arguments, made clsewhere in constitutional theory discourse, that federal courts should underenforce constitutional norms or otherwise sanction the existence of constitutional rights without remedies. See, e.g., Lawrence Gene Sager, Fair Measure: The Legal Status of Underenforced Constitutional Norms, 91 Harv. L. Rev. 1212 (1978). But cf. Daryl J. Levinson, Rights Essentialism and Remedial Equilibration, 99 Colum. L. REV. 857 (1999) (arguing that constitutional rights and remedies are intertwined to an extent that it is nonsensical to talk about the possibility of rights without remedies).

167. See Sunstein, Standing After Lujan, supra note 63, at 215, 216-17 (explaining that Scalia's position has no basis in the text or history of the Constitution); see also Sunstein, Informational Standing, supra note 63, at 645-46. 
implications. In the constitutional context, it would bar judicial review of a federal law that clearly violated a specific constitutional provision, so long as the law's injury fell broadly on a majority of the polity. In addition, the argument is grounded in a rather crude theory of democracy. Scalia seems to argue that there is no need for courts to intervene to remedy majoritarian injuries because the majority will exercise its power in the democratic process to do so. ${ }^{168}$ But this argument is too simplistic. Minorities often wield substantial political power. ${ }^{169}$ And some majorities carry little political influence, either because they are too diffuse or for other reasons. ${ }^{170}$

There is perhaps more reason to fear such problems with the political process in the context of immigration law than in other contexts. Immigration law constitutes the political community by excluding certain categories of people. Those who are excluded are, by definition, legally disabled from asserting their interests in the political process. ${ }^{171}$ Therefore, while Scalia's democracy argument assumes the existence of a closed community on which the law operates, immigration law is actually squarely concerned with the very construction of that community.

All of this said, it is beyond the scope of this Article to construct a robust theory of when judicial intervention should be available to remedy widely shared expressive injuries. Constructing such a theory would require answering, at least partially, difficult questions about what constitutes the appropriate role of Article III courts in our democratic society, how and when courts should interpret the substantive guarantees of the Constitution to confer a cause of action on a person or group of people, and how the institutional capacity of courts to account for the social meaning of regulation should affect the answers to those two questions. My point, therefore, is not that citizens should always, as a matter of constitutional theory, have standing to complain about expressive injuries. Rather, my point is only that there is no persuasive institutional objection to citizen standing in all such cases. Together with the Shaw cases' strong support for the position that political community members should sometimes have standing to contest the construction of their community boundaries, this conclusion undermines the argument that community-wide injuries inflicted by immigration law should always be left to the political process.

168. See Scalia, supra note 163 , at $894-97$

169. See, e.g., Russell Hardin, Collective Action (1982); Mancur Olson, The logic of Collective Action: Public Goods and the Theory of Groups (2d prtg. 1971).

170. Sunstein, Standing After Lujan, supra note 63, at 219-20; Sunstein, Informational Standing, supra note 63 , at $646-47$. In fact, if the democratic process worked in such a perfectly majoritarian fashion, one might ask why majoritarian injuries would ever arise.

171. Today, no states permit resident aliens to vote in national elections. See NEuman, supra note 3, at 70 . And, obviously, aliens outside the country cannot vote. 
In short, citizens should have standing to challenge immigration policy under many circumstances. Courts have recognized this sporadically, but they should acknowledge it more consistently. Moreover, one should not mistake the associational and economic injuries that courts have thus far recognized to be a comprehensive list of the judicially cognizable interests of citizens that immigration law implicates. Because immigration law regulates the American community, it can injure existing members of that community. Citizens should have standing where they suffer such injuries.

III

\section{The Implications of Citizen Standing}

Recognizing that citizens should have standing to challenge immigration policy in many circumstances has substantial implications for constitutional immigration law. It clarifies that citizens frequently should have the right to seek judicial review of the constitutionality of immigration lawssomething aliens generally lack the capacity to do. And because plenary power doctrine is in large part a doctrine of standing, it should operate less forcefully when citizens' rights are at stake. In short, the insight that plenary power doctrine is largely a doctrine of standing, combined with the acknowledgement that citizens sometimes have standing to challenge immigration law, makes clear that immigration policy should not be insulated from compliance with conventional constitutional norms, as contemporary immigration jurisprudence suggests.

\section{A. Constitutional Challenges to Immigration Policy}

Once one recognizes that citizens regularly have standing to challenge immigration law, it becomes clear that citizens can, in many circumstances, challenge the constitutionality of immigration policy. As the Supreme Court has held, a party that has standing can typically challenge the action giving rise to standing on any legal ground. ${ }^{172}$ Thus, citizens who have standing to challenge immigration laws by virtue of associational, economic, expressive, or other sorts of injuries should regularly be able to raise constitutional challenges to those laws.

To be more concrete about what this means in practice, consider the archetypical immigration policies that plenary power doctrine has largely insulated from constitutional attack-policies pursuant to which aliens have been excluded from the country or otherwise subject to worse immigration treatment because of their ideology, race, or religion. These are the

172. Duke Power Co. v. Carolina Envtl. Study Group, Inc., 438 U.S. 59, 78-81 (1978). The Duke Power Court rejected the contention that a plaintiff asserting a constitutional challenge "must demonstrate a connection between the injuries they claim [for standing purposes] and the constitutional rights being asserted." Id. at 78 . 
sorts of immigration policies on which academic criticism has focused. ${ }^{173}$ More important, such policies are not far removed from contemporary reality. Expressly race-based exclusionary policies like those embodied by the Chinese Exclusion Acts are no longer part of American immigration law, but there are many contemporary immigration policies that commentators argue discriminate on the basis of ideology, race, or religion. ${ }^{174}$

Since the attacks of September 11 th, the possibility of discriminatory immigration policies has only increased. In the wake of September 11 th, the Department of Justice has implemented several new regulations that selectively enforce immigration law. Under its special registration program, for example, aliens in the United States from countries that the federal government designates as sources for potential terrorists are now required to report to the INS to be fingerprinted, photographed, and possibly interviewed. ${ }^{175}$ Nearly all the designated countries are predominantly Muslim, and some human rights groups have argued that the program is a form of racial profiling. ${ }^{176}$ In addition to establishing the registration

173. See, e.g., Chin, supra note 3.

174. See, e.g., Charles J. Ogletree, Jr., America's Schizophrenic Immigration Policy: Race, Class, and Reason, 41 B.C. L. REv. 755, 761 (2000) (arguing that "implicit and explicit racial biases still pervade all four major avenues of legal immigration: family-sponsored, employment-based, diversity and refugee"); Malissia Lennox, Note, Refugees, Racism, and Reparations: A Critique of the United States' Haitian Immigration Policy, 45 STAN. L. REv. 687, 704 (1993) (arguing that "racial discrimination is the driving force" behind the differential treatment of Cuban and Haitian refugees). Moreover, courts continue to conclude that even outright racial or religious discrimination is permissible in immigration law. See, e.g., Jean v. Nelson, 727 F.2d 957, 964 n.5 (11 th Cir. 1984) (en banc) (stating that aliens may "be denied admission on grounds that would be constitutionally impermissible or suspect in the context of domestic legislation"), aff 'd, 472 U.S. 846 (1985); see also Harisiades v. Shaughnessy, 342 U.S. 580, 597 (1952) (Frankfurter, J., eoncurring) ("But whether immigration laws have been crude and cruel, whether they may have reflected xenophobia in general or anti-Semitism or anti-Catholicism, the responsibility belongs to Congress.").

175. See Registration of Certain Nonimmigrant Aliens From Designated Countries, 68 Fed. Reg. 8046 (Feb. 19, 2003); 68 Fed. Reg. 2363 (Jan. 16, 2003); 67 Fed. Reg. 77,642 (Dec. 18, 2002); 67 Fed. Reg. 77,136 (Dec. 16, 2002); 67 Fed. Reg. 70,526 (Nov. 22, 2002); 67 Fed. Reg. 67,766 (Nov. 6, 2002); 67 Fed. Reg. 57,032 (Sept. 6, 2002); see also Karen Tumlin, Suspect First: How Terrorism Policy Is Reshaping Immigration Policy, 92 CALIF. L. REv. (forthcoming July 2004). See generally 8 U.S.C. $\$ \S 1303($ a) (authorizing the Attomey General to prescribe special registration for certain classes of aliens) (2000); 8 C.F.R. $§ 264.1$ (f) (2003) (same). Relatedly, after September 11 th the Department of Justice established the Interview Project, which aimed to interview over 5,000 men from countries with "an Al Qaeda terrorist presence." See Memorandum from Kenneth Wainstein, Director of the Executive Office for United States Attorneys, Final Report on Interview Project (Feb. 22, 2003) (on file with author). While this initiative was not directly concerned with immigration enforcement, some interviewees were placed in deportation proceedings when the interview process uncovered technical immigration violations. See Tumlin, supra.

176. See, e.g., Press Release, American Civil Liberties Union, ACLU Calls Immigrant Registration Program Pretext for Mass Detentions (Dec. 19, 2002), available at http://www.aclu.org/ SafeandFree/SafeandFree.cfm $? \mathrm{ID}=11503 \& \mathrm{c}=206$; American Immigration Lawyers Association, Executive Actions Threaten Fundamental Freedoms, available at http://www.aila.org/ fileViewer.aspx?doclD=9847; Amy Yee, Red Tape, Green Cards and Visa Blues, FIn. TImEs, Feb. 20, 2003, available at 2003 WL 14177506; $c f$. Letter from Russell D. Feingold, Edward M. Kennedy, and John Conyers Jr. to John D. Ashcroft (Dec. 23, 2002), available at http://www.adc.org/ 
program, the federal government is pursuing similarly selective immigration policies through the Absconder Initiative, which targets aliens from "al Qaeda" nations for removal, ${ }^{177}$ as well as through Operation Liberty Shield, which subjects asylum applicants from many such countries to mandatory detention. ${ }^{178}$ While the federal government has stated that the new policies are not based on race, ethnicity, or religion, commentators have argued that these criteria have played a role in the formulation of immigration policies in the wake of the terrorist attacks. ${ }^{179}$

Citizens with standing should be able to test the constitutionality of these allegedly discriminatory immigration policies. ${ }^{180}$ They could assert First Amendment claims against the ideological exclusion of classes of aliens, equal protection challenges to immigration decisions made on the basis of race or nationality, and Establishment Clause and perhaps equal protection challenges to immigration policies that either favor or disfavor certain religions, or religion generally.

As discussed earlier, courts have considered the possibility of citizen standing to bring only a small subset of these potential constitutional claims. Because courts currently have an unduly cabined understanding of citizen standing in immigration law cases, they have largely confined constitutional challenges by citizens to narrow situations in which citizens' associational interests are at stake. The Supreme Court, for example, has accorded citizens standing to assert constitutional claims against immigration policy only in situations concerning invited speakers and family members. (And, as Part III.B explains, even in these cases the Court has not recognized the implications of permitting such claims.) First, the Court has granted citizens standing to raise First Amendment challenges in cases in which a speaker who has been invited by citizens is excluded by the government on the basis of his ideology. ${ }^{181}$ Second, the Court has accorded a

index.php?id=1570 (contending that the special registration program targets persons on the basis of race and religion).

177. See Memorandum from the Deputy Attomey General, U.S. Department of Justice, Guidance for Absconder Apprehension Initiative (Jan. 25, 2002), available at http://news.findlaw.com/ hdocs/docs/doj/abscndr012502mem.pdf.

178. See, e.g., U.S. Dep't of Homeland Security, Press Kit: Operation Liberty Shield, at http://www.dhs.gov/dhspublic/display? content=520 (last visited Oct. 30, 2003) (announcing policy of mandatory detention for asylum seekers from all nations "where al-Qaeda, al-Qaeda sympathizers, and other terrorist groups are known to have operated").

179. See, e.g., David Cole, We've Aimed, Detained and Missed Before, Wash. Post, June 8, 2003, at Bl; David Cole, Driving While Immigrant, The NATION, May 12, 2003, at 6; Rachel L. Swarns, Thousands of Arabs and Muslims Could Be Deported, Officials Say, N.Y. TIMEs, June 7, 2003, at A1; sources cited supra note 176.

180. Whether they could succeed on the merits is, of course, another matter. The likelihood of success on the merits would turn in part on what, if any, role plenary power doctrine would continue to play in such cases. That possibility is discussed below. See infra text accompanying notes 205-14.

181. See Kleindienst v. Mandel, 408 U.S. 753, 762-65 (1972); see also Harvard Law Sch. Forum v. Shultz, 633 F. Supp. 525, 529 (D. Mass. 1986), vacated, 852 F.2d 563 (1st Cir. 1986) (unpublished table decision); Allende v. Shultz, 605 F. Supp. 1220, 1222 n.1 (D. Mass. 1985); Abourezk v. Reagan, 
citizen standing to assert an equal protection challenge against an immigration decision that affects a family member or close relative and that is contingent on the sex of a citizen, rather than an alien. ${ }^{182}$ As Part 11 demonstrates, however, citizen standing to assert constitutional challenges should not be limited to instances in which family members are excluded from the country; nor should it be restricted to situations in which the immigration policy discriminates on the basis of the citizen's race.

One might object to broader citizen standing to challenge the racial, ideological, or religious exclusion of aliens on the ground that citizens in such cases would really be asserting the rights of aliens, rather than their own rights. Contemporary standing doctrine's prudential component limits the circumstances in which one party will be given standing to assert the legal rights of another. ${ }^{183}$ So, for example, one might claim that granting citizen standing to challenge the exclusion of a class of aliens on the basis of the aliens' race would require permitting citizens to assert the rights of the aliens, rather than their own rights.

While third-party standing doctrine retains its formal status as a prudential standing limitation, the rule that a litigant cannot assert the rights or interests of others is riddled with exceptions. ${ }^{184}$ Beyond this, there are deep conceptual problems with third-party standing doctrine. It is far from clear, for example, that third-party standing questions are conceptually any different than other standing questions. ${ }^{185}$ As with standing jurisprudence generally, the questions posed by third-party standing doctrine do not concern only the trans-substantive question of the conception of adjudication embodied by Article III; rather, third-party standing questions largely concern the conceptual structure of legal rights (and, in constitutional cases, the structure of constitutional rights). ${ }^{186}$ In other words, the argument that the citizens in the above example would be asserting the constitutional rights of the excluded aliens is grounded in a particular conception of the constitutional right protected by the Equal Protection Clause. That conception may well be wrong. ${ }^{187}$

Nonetheless, even taking third-party standing doctrine on its own terms and utilizing uncontroversial (though perhaps incorrectly limited)

592 F. Supp. 880 (D.D.C. 1984), vacated on other grounds, 785 F.2d 1043 (D.C. Cir. 1986), aff'd by an equally divided Court, 484 U.S. 1 (1987).

182. See Nguyen v. INS, 533 U.S. 53 (2001); Fiallo v. Bell, 430 U.S. 787 (1977).

183. See, e.g., Warth v. Seldin, 422 U.S. 490,499 (1975) ("[E]ven when the plaintiff has alleged injury sufficient to meet the 'case or controversy' requirement, this Court has held that the plaintiff generally must assert his own legal rights and interests, and cannot rest his elaim to relief on the legal rights or interests of third parties.").

184. See, e.g., Fletcher, supra note 63 , at $243-47$ \& n.103.

185. See id. at 244-45.

186. See Matthew D. Adler, Rights Against Rules: The Moral Structure of American Constitutional Law, 97 MiCH. L. REv. 1, 133-35 (1998).

187. See id. 
doctrinal assumptions about whose constitutional rights are at stake in certain cases, it is wrong to think that citizens would not be asserting their own rights were they to challenge alleged racial, religious, or ideological discrimination in immigration policy. As the voting rights discussion in Part II.C demonstrates, the self-definitional aspects of government regulations that structure the boundaries of a political community can lead those regulations to impinge upon the constitutional rights of existing community members.

Consider, for example, an immigration law that excluded, expelled, or otherwise regulated aliens on the basis of the aliens' race. Were citizens to attack such an immigration policy on the ground that it violated the Equal Protection Clause by expressing an impermissibly racialized conception of national political identity, the Shaw cases make clear that there would be no question that the citizens were asserting their own-as opposed to the excluded aliens'-constitutional rights. ${ }^{188}$

If this seems odd, it is only because of the common law-based legal intuition that only the rights of the "direct subjects" of a governmental action can be infringed by that action. As Part II showed, however, that intuition is often misleading. Even the Court has acknowledged this. In the ideological exclusion case Kleindienst $v$. Mandel, for example, the Court had no difficulty understanding that citizens' rights were at stake, even though they were not the direct subjects of the immigration regulation. ${ }^{189}$ Establishment Clause jurisprudence provides similar examples. Citizens could challenge religious immigration exclusions on constitutional grounds that uncontroversially would be considered to be based on their own rights, rather than on the rights of aliens. Under the Establishment Clause, courts have regularly indicated that government action favoring a particular religion, and perhaps religion generally, implicates the constitutional rights of believers and nonbelievers of every type. ${ }^{190}$ For that reason, a citysponsored crèche can be challenged by a devout Christian, as well as by a Buddhist, Muslim, or atheist. ${ }^{191}$ In line with this conception of the Establishment Clause, citizens should have standing to assert Establishment Clause challenges against, for example, a government asylum policy that systematically favors religious persecution claims by Christians. Similarly, citizens should be able to bring Establishment Clause

188. See supra text accompanying notes 111-19.

189. 408 U.S. $753,754,756-57,762-65$ (1972).

190. Cf. Bowen v. Kendrick, 487 U.S. 589, 619 (1988) (granting federal taxpayers standing to raise Establishment Clause claim without inquiring into their religious beliefs or lack thereof); Flast $\mathrm{v}$. Cohen, 392 U.S. 83, 88 (1968) (same).

191. See, e.g., County of Allegheny v. ACLU, 492 U.S. 573, 587-88 (1989) (plurality opinion) (adjudicating plaintiffs' Establishment Clause challenge to county's display of crèche, without inquiring into the religious beliefs of the plaintiffs). 
challenges to post-September 11 th policies that arguably disfavor Muslims in the asylum process, the visa application process, and elsewhere. ${ }^{192}$

The above illustrations are far from a comprehensive list of the types of constitutional challenges that citizens might be able to assert against immigration laws. ${ }^{193}$ These examples demonstrate, however, that citizens should be able to assert constitutional challenges to much broader swaths of immigration law than courts have previously recognized.

\section{B. Undermining the Plenary Power}

Broader standing does not mean, of course, that these challenges will succeed on the merits. Nor does it necessarily mean that plenary power doctrine will have no continuing force in cases in which citizens can raise constitutional challenges to immigration law. This section demonstrates, however, that there should be substantially more judicial scrutiny of immigration law for compliance with constitutional norms when citizens assert constitutional challenges.

Although the Supreme Court has on a few occasions permitted citizens to raise constitutional challenges to immigration laws, ${ }^{194}$ it has formally refused to evaluate citizen challenges any differently than challenges by aliens. ${ }^{195}$ In Kleindienst $v$. Mandel, ${ }^{196}$ the first case in which the Supreme Court permitted citizens to raise a constitutional challenge to an immigration action, the Court described the plenary power much as it had done in previous cases concerning aliens' rights. According to the Court, the federal government's exercise of its immigration power was largely immune from judicial review, and this remained true even though citizens

192. Cf. County of Allegheny, 492 U.S. at 590-91 (majority opinion) ("[T]his Court has come to understand the Establishment Clause to mean that government may not ... discriminate among persons on the basis of their religious beliefs and practices.").

193. Other potential constitutional challenges would include claims that immigration policy violates structural constitutional norms, such as those regulating the separation of powers. When structural eonstraints are at stake, courts generally have little trouble thinking that nearly anyone injured by the policy can attack the asserted illegality, because courts do not gct hung up on questions of who "possesses" the structural constitutional right. See, e.g., INS v. Chadha, 462 U.S. 919 (1983).

194. See supra notes 181-82; see also Nguyen v. INS, 533 U.S. 53 (2001); Fiallo v. Bell, 430 U.S. 787 (1977); Kleindienst v. Mandel, 408 U.S. 753 (1972).

195. See Fiallo, 430 U.S. at 794, 795 n.6; Mandel, 408 U.S. at $776-77.1$ say "formally" because the Court recently appeared to reserve the question whether immigration laws that implicate the rights of citizens should be scrutinized more closely. In Nguyen, the Court evaluated a citizen father's constitutional challenge to a gender-based naturalization regulation using standard cqual protection analysis. It asked whether the classification served important governmental objeetives and whether the discriminatory means employed were substantially related to the achicvement of those objeetives. Nguyen, 533 U.S. at 60-61 (citing United States v. Virginia, 518 U.S. 515 (1996)). After concluding that the regulation satisfied intermediate scrutiny, however, the Court was careful to note that it "need not decide whether some lesser degree of scrutiny pertains because the statute implicates Congress' immigration and naturalization power." Id. at 61 ; see also id. at 72-73.

196. 408 U.S. 753 (1972). 
were seeking that review. ${ }^{197}$ The Court made clear that it would not test the government's purpose for the immigration decision "by balancing its justification against the First Amendment interests of [the citizen plaintiffs]." ${ }^{198}$ In Fiallo v. Bell, ${ }^{199}$ the Court was even more blunt. The citizen plaintiffs in Fiallo argued explicitly that the Court should "scrutinize congressional legislation in the immigration area to protect against violations of the rights of citizens." ${ }^{200}$ The Court disagreed:

[T]his Court has resolved similar challenges to immigration legislation based on other constitutional rights of citizens, and has rejected the suggestion that more searching judicial scrutiny is required. ... Our cases do make clear that despite the impact of these classifications on the interests of those already within our borders, congressional determinations such as this one are subject only to limited judicial review. ${ }^{201}$

The Court's assessment of the relevance of citizens' rights is flawed. As Part I explained, the plenary power is in part a standing doctrine: the doctrine regularly justifies insulating immigration laws from constitutional challenge on the ground that aliens lack the rights necessary to challenge those rules in any meaningful way. ${ }^{202}$ This alien rights-based justification is

197. Id. at 776-77.

198. Id. at 770. It is possible to interpret the Court's conventional recitation of the plenary power as simply the result of the plaintiff's litigation strategy: they may have eonceded that the foree of the plenary power was unaffected by the presenee of citizen plaintiffs. See id. at 767 . It also might be possible to interpret Mandel as applying more judicial scrutiny than the Court acknowledged. Before upholding Mandel's exclusion, the Court did go to great pains to explain that the INS had denied Mandel's visa for reasons that were, at least on their face, uneonnected to his ideology or the purpose of his visit. But even if one thought Mandel ambiguous, Fiallo v. Bell, 430 U.S. 787 (1977), at least formally dissolved any ambiguity in the doctrine by stating straightforwardly that the Court did not distinguish between citizen and alien challenges to immigration policy.

199. 430 U.S. 787 (1977)

200. Id. at 794 .

201. Id. (citing Kleindienst v. Mandel, 408 U.S. 753 (1972)); see also id. at 795 n.6. In both Fiallo and Mandel, the Court's conclusion that the presence of citizen rights was irrelevant evoked strenuous dissents. See Fiallo, 430 U.S. at 809 (Marshall, J., dissenting) ("[D]iscrimination among citizens cannot escape traditional constitutional scrutiny simply because it occurs in the context of immigration legislation."); Mandel, 408 U.S. at 771-72 (Douglas, J., dissenting) ("While Dr. Mandel, an alien who seeks admission, has no First Amendment rights while outside the Nation, the other appellees are on a different footing. ... Even assuming, arguendo, that those on the outside seeking admission have no standing to complain, those who hope to benefit from the traveler's lectures do.") (emphasis added); id. at 782 (Marshall, J., dissenting) (arguing that Mandel's exclusion should not be evaluated under the doetrine set forth in The Chinese Exclusion Case, 130 U.S. 581 (1889), and other plenary power cases, because "none of [those cases] was concerned with the rights of American citizens. ... At least when the rights of Americans are involved, there is no basis for concluding that the power to exclude aliens is absolute"). It is important to note, however, that the dissents may have overstated the relevance of citizen standing. Marshall, for example, appears to argue that the presence of citizen standing renders plenary power doctrine entircly irrelevant. See Fiallo, 430 U.S. at 809 (Marshall, J., dissenting); Mandel, 408 U.S. at 777, 779, 781 (Marshall, J., dissenting). As the following discussion explains, however, such a conclusion may be mistaken. See infra text accompanying notes 205-15.

202. See supra notes 56-67 and accompanying text. 
irrelevant in cases concerning citizen rights. For while there are several reasons that aliens are considered to have no (or very limited) rights with respect to immigration law, these reasons do not apply to citizens. According to courts, aliens lack rights because of things like their lack of membership in the constitutional community and the territoriality of constitutional protections. ${ }^{203}$ In other words, aliens lack constitutional rights to challenge immigration law by virtue of their status, not solely by virtue of the nature of the law they seek to challenge. As the Supreme Court has frequently stated, "[i]n the exercise of its broad power over naturalization and immigration, Congress regularly makes rules that would be unacceptable if applied to citizens."204

If the standing justification does not operate in cases concerning citizens' rights, then plenary power doctrine must function differently in such cases. Because this justification cannot in such cases provide a basis on which a court can reject a constitutional challenge, courts will have to rethink the reasons why - and the extent to which-immigration law should be insulated from judicial scrutiny for compliance with constitutional norms.

It is true, of course, that the standing conception of plenary power doctrine is not the doctrine's only justification. As I explained above, the insulation of immigration law from constitutional challenge is also justified on other grounds: the content of the power is frequently grounded in judicial deference to the political branches, and it is sometimes based on notions of a sovereign prerogative that is entirely unconstrained by the Constitution. ${ }^{205}$ Thus, determining the precise implications for judicial review of removing one conceptual basis would require an understanding of the analytical relationship between the three bases. But courts have not expressly acknowledged the typology of justifications set forth in this Article, let alone explained the relationship among them. ${ }^{206}$ More than that, the doctrinal relationship between the justifications appears to be incoherent. ${ }^{207}$

Despite this confusion, it is clear that plenary power doctrine should operate less forcefully when citizens' rights are at stake. For regardless of whether one can construct an analytical framework that describes how the different justifications operate in conjunction (either in doctrine or in theory), courts have never suggested that each conception is independently sufficient to limit judicial review as severely as does current doctrine. ${ }^{208}$ To

203. See supra notes 65-67.

204. Mathews v. Diaz, 426 U.S. 67, 79-80 (1976).

205. See supra Part 1.A-B.

206. See supra text accompanying notes 33-34.

207. See id.

208. Or, to put it differently, there is no suggestion that the doctrine is overdetermined such that eliminating the standing basis for insulating immigration law would have no effect on the substance of Congress's plenary power over immigration. 
the contrary, courts appear to draw support from each of the conceptions to support the near-immunity of immigration law from constitutional review, frequently referring in one breath to the different conceptions of the plenary power. ${ }^{209}$ Thus, the different categories of plenary power conceptions operate much as redundant justifications do throughout much of the law: each provides a measure of the justificatory support necessary to carry the weight of the existing doctrinal structure. At a minimum, therefore, the plenary power should operate less forcefully where the standing justification is inapplicable because citizens' rights are at stake. ${ }^{210}$ Moreover, the absence of the standing justification for plenary power doctrine's judicial insulation of immigration law may force courts to reevaluate the entirety of the doctrine's foundations.

It would be surprising, for example, to find that the unlimited congressional power justification was itself sufficient to insulate immigration law from constitutional challenges by citizens. This basis for the plenary power, while appearing in the earliest plenary power cases, is the least well justified as a matter of constitutional text and history. In fact, there is reason to think that, even when the Court appears to articulate the unlimited power justification, it is actually referring to the judicial deference or standing conceptions. When the unlimited power justification is suggested, for example, it is generally referred to in close conjunction with these other conceptions of the power. Moreover, the Court has on more than one

209. Fiallo v. Bell, 430 U.S. 787 (1977), provides a good example of the Court's invoking, in one breath, all three conceptual justifications for the plenary power. At the outset of the discussion in that case, the Court set about to justify "the limited scope of judicial inquiry into immigration legislation." Id. at 792. First, the Court described the power as unconstrained by the Constitution, noting that it had "long recognized the power to expel or exclude aliens as a fundamental sovereign attribute exercised by the Govemment's political departments largely immune from judicial control." Id. This statement, in addition to gesturing to an extraconstitutional power inhering in sovereignty, hints at the notion of political question-esque judicial deference. The Court articulated this latter conception more forcefully just a few sentences later: "“[T] he power over aliens is of a political character and therefore subject only to narrow judicial review." Id. (quoting Hampton v. Mow Sun Wong, 426 U.S. 88, 101 n.21 (1976)) (emphasis added). Third, the Court suggested that plenary power doctrine is the product of aliens' laek of constitutional rights, noting that Congress is permitted in the context of immigration to make "rules that would be unacceptable if applied to citizens." Id. (quoting Mathews v. Diaz, 426 U.S. $67,80(1976))$.

210. In fact, this insight into the structure of plenary power doctrine may have subtle effects even in cases that do not concern laws that implicate citizens' rights. Part of the rhetorie of plenary power case law, particularly in the lower courts, is that Congress can do whatever it wants with respect to immigration-up to and including the adoption of explicitly racially discriminatory immigration policies. See, e.g., Jean v. Nelson, 727 F.2d 957, 978 (11th Cir. 1984) (en banc) (suggesting that Congress could constitutionally enact immigration policies that discriminate on the basis of national origin), aff $d, 472$ U.S. 846 (1985). The starkness of this continued suggestion likely affects, in subtle ways, other aspects of immigration jurisprudence. 1t makes more plausible courts' holdings in other contexts involving aliens' rights, sueh as the conclusion of many circuits that exeludable aliens are unprotected by the due process clause. See, e.g., Carrera-Valdez v. Perryman, 211 F.3d 1046 (7th Cir. 2000); Chi Thon Ngo v. INS, 192 F.3d 390 (3d Cir. 1999). 
occasion expressly disavowed that Congress is subject to no constitutional limitations when it exercises its immigration power. ${ }^{211}$

The judicial deference justification for plenary power doctrine, being more plausibly defensible in light of American constitutional traditions, may well continue to operate in plenary power cases. There are, of course, reasons to question whether it will. The political question doctrine and other doctrines of nonjusticiability are in decline in constitutional law, ${ }^{212}$ and one might expect the plenary power's closely related judicial deference basis similarly to wane.$^{213}$ But even if the judicial deference justification retains its purchase, it does not support the near complete insulation of immigration law from constitutional challenge. Rather, it suggests only that courts should be somewhat deferential in their constitutional review of congressional immigration policy. ${ }^{214}$

In practice, this should mean that courts will enforce conventional constitutional limitations in citizen suits challenging immigration policy, but that courts may limit the closeness of their scrutiny by adopting presumptions or proof structures that are somewhat different from those courts employ when adjudicating constitutional challenges to other laws. ${ }^{215}$ Thus, for example, where a constitutional claim against an immigration action turns on the government's purpose for undertaking that action, courts might be somewhat less likely than they would be in other cases to look as far behind the government's stated purpose.

In fact, there are a few instances in which lower courts appear to have undertaken just this sort of review. In several recent ideological exclusion cases brought by citizens, Iower courts have suggested-contrary to the Supreme Court's admonition in Fiallo-that more searching review is available in plenary power cases where the constitutional rights of citizens are at stake. ${ }^{216}$ Specifically, the courts in those cases have insisted that

211. In INS v. Chadha, 462 U.S. 919 (I983), for instance, the Court held that:

The plenary authority of Congress over aliens ... is not open to question, but what is challenged hcre is whether Congress has chosen a constitutionally permissible means of implementing that power. As we made clear in Buckley v. Valeo, 424 U.S. I (I976): "Congress has plenary authority in all cases in which it has substantive legislative jurisdiction, so long as the exercise of that authority does not offend some other constitutional restriction."

Id. at 940-41 (some citations omitted); see also Zadvydas v. Davis, 533 U.S. 678, 695 (2001) ("The Government also looks for support to cases holding that Congress has 'plenary power' to create immigration law .... But that power is subject to important constitutional limitations.").

212. See Barkow, supra note 37.

213. See Aleinikoff, supra note 32, at 164-65.

214. See supra notes 41-43 and accompanying text.

215. The different levels of scrutiny that the Court employs in equal protection challenges present a similar example of how a court can accord varying degrees of deference while enforcing the same underlying constitutional constraint. See Clark v. Jeter, 486 U.S. 456, 461 (1988) (discussing the three levels of scrutiny and the types of laws to which each level of scrutiny applies).

216. See, e.g., Harvard Law Sch. Forum v. Shultz, 633 F. Supp. 525, 529 (D. Mass. 1986) ("The exercise of judicial review. ... is particularly appropriate in cases like the one at bar which involve 
conventional First Amendment norms govern the federal government's exercise of its immigration power. As one court stated:

[A]n alien invited to impart information and ideas to American citizens... may not be excluded... solely on account of the content of his proposed message. For although the government may deny entry to aliens altogether, or for any number of specific reasons, it may not, consistent with the First Amendment, deny entry solely on account of the content of speech. ${ }^{217}$

To be sure, these courts still engaged in somewhat less searching review than would normally be the case outside of the immigration context: they evaluated the government's reasons for excluding a person from the country, but indicated that they would not scrutinize those reasons for pretext as closely as they might in a First Amendment case concerning domestic regulations. $^{218}$ The mechanics of deference aside, however, the courts clearly required the federal government to comply with First Amendment norms.

In short, courts should measure immigration policy against constitutional constraints when citizens assert constitutional claims against immigration law. Contrary to the Supreme Court's assertion, citizen standing does undermine the force of plenary power doctrine.

\section{CONCLUSION}

Given that aliens are the obvious, primary subjects of immigration law, it is not surprising that little attention has been paid by courts and scholars to the legal relationship between citizens and immigration policy. As this Article has demonstrated, however, examining immigration law from the perspective of citizens reveals two obscured points.

First, plenary power doctrine should be responsive to citizens' rights. The justification that aliens lack the right to seek judicial review of the constitutionality of immigration Iaws-a principal justification underlying plenary power doctrine-is absent when citizens' rights are stake. Plenary

fundamental rights of United States citizens."), vacated, 852 F.2d 563 (1 st Cir. 1986) (unpublished table decision); see also Allende v. Shultz, No. 83-3984-C, 1987 WL 9764, at *2 (D. Mass Mar. 31, 1987) (citing Fiallo v. Bell, 430 U.S. 787, 793 n.5 (1977)), aff d, 845 F.2d 1111 (1st Cir. 1988); Allende v. Shultz, 605 F. Supp. 1220, 1223 (D. Mass. 1985) (citing Kleindienst v. Mandel, 408 U.S. 753 (1972)); Abourezk v. Reagan, 592 F. Supp. 880 (D.D.C. 1984), vacated on other grounds, 785 F.2d 1043 (D.C. Cir. 1986), aff'd by an equally divided Court, 484 U.S. 1 (1987). Cf. Adams v. Baker, 909 F.2d 643, 647-48 (1st Cir. 1990) (purporting to follow Fiallo, but appearing actually to agree that the government is bound by First Amendment norms when it makes visa decisions). Interestingly, these courts have read $\mathrm{Mandel}$ to provide the basis for their conclusion that citizen challenges to immigration policy deserve greater review.

217. Abourezk, 592 F. Supp. at 887; accord Harvard Law Sch. Forum, 633 F. Supp. at 531; Allende, 605 F. Supp. at 1225.

218. See Harvard Law Sch. Forum, 633 F. Supp. at 531 (employing scrutiny restricted to the "limited review contemplated by Mandel"); Allende, 605 F. Supp. at 1223 (noting that judicial review was "necessarily limited in scope"); Abourezk, 592 F. Supp. at 881. 
power doctrine may not collapse entirely without this support, but it certainly should operate less forcefully.

Second, viewing immigration law through the lens of citizens' rights reveals that those rights are much more frequently implicated by immigration policy than conventional wisdom suggests. Immigration law can implicate the economic and associational interests of citizens. Perhaps more importantly, citizens have a substantial stake in immigration law because it plays a central role in defining our national community. Immigration policy can injure citizens by expressing impermissible notions of national identity, and such injuries may be constitutionally cognizable. This does not necessarily mean that immigration law must be subject to identical judicial review - or even necessarily the very same constitutional constraints - as domestic law. It does mean, however, that citizens should more frequently have standing to seek a judicial determination of what those constraints are.

In arguing that courts and scholars should examine immigration law from the standpoint of citizens, I do not mean to suggest that this perspective is superior to others. It remains vitally important, both as a matter of law and policy, to evaluate immigration law's implications for aliens. In addition, it is crucial that scholarship continue to question the current status of aliens in our political and constitutional community. Far from undermining those inquiries, this Article seeks simply to supplement them. But the additional perspective is important: it reveals that immigration law can infringe citizens' constitutional rights, and that immigration policy should be responsive to those rights. 
